\title{
Repeated post-Caledonian intra-cratonic rifting in the central North Sea: Evidence from the volcanic record in the Embla oil field
}

\author{
A.M. Lundmark ${ }^{\mathrm{a}}$, R.H. Gabrielsen ${ }^{\mathrm{a}}$, T. Strand ${ }^{\mathrm{b}}$, S.E. $\mathrm{Ohm}^{\mathrm{c}}$ \\ ${ }^{a}$ Department of Geosciences, P.O. Box 1047, University of Oslo, N-0316, Oslo, Norway \\ ${ }^{\mathrm{b}}$ ConocoPhillips Norge, P.O. Box 220, N-4098, Tananger, Norway \\ ${ }^{\mathrm{c}}$ Department of Petroleum Engineering, University of Stavanger, 4036 Stavanger, Norway
}

\begin{abstract}
Intrusive and extrusive mafic igneous rocks in the Embla oil field, central North Sea, testify to repeated postCaledonian magmatism on the northern flank of the Mid North Sea High. The igneous rocks are highly clay- and carbonate-altered, but retain their High Field Strength element signatures on the sample scale. These signatures are used to group, classify and investigate the tectonic significance of the rocks. Three magmatic events are identified. Late Devonian transitional basalts are interpreted as part of a bimodal volcanic assemblage that includes ca. 375 Ma alkali rhyolites, suggested to record rifting in a proto-Central Graben. Early Permian volcanic and hypabyssal alkaline rocks in the Embla oil field display lamprophyric traits and represent low degree melts. They likely correlate either to ca. 300 Ma lamprophyre magmatism leading up to, or 298-292 Ma alkaline magmatism in the Midland Valley - Southern Uplands coeval with the northwest European magmatic flare-up at the Permo-Carboniferous boundary. Kimmeridgian-Tithonian submarine tholeiitic basalts in the Embla oil field post-date the alkaline continental mid Jurassic magmatism associated with doming and initial rifting in the North Sea, and are suggested to represent a hitherto unknown volcanic expression of the late Jurassic main rift phase in the Central Graben.
\end{abstract}

\section{Introduction}

Intra-continental rifting and basin formation are commonly associated with magmatism. This is particularly so when the extension reflects plume activity, i.e. active rifting, but also when extension is passive and reflects farfield stresses (Şengör and Burke, 1978). The magmatic rocks represent a valuable tool for basin analysis, potentially providing relative and absolute time constraints and enabling long range correlation of strata (Altermann and Nelson, 1998). In addition, they can help reveal the extent and depth of melting (Latin et al., 1990) and the nature of the magma source region (Kirstein et al., 2006), thus shedding light on the tectonomagmatic evolution. In the Embla oil field on the northern flank of the Mid North Sea High, central North Sea (Fig. 1), mafic igneous intervals are found in both the Palaeozoic reservoir and the Mesozoic cap rock sequences. The terrestrial reservoir rocks are difficult to date due to oxidation of organic material, which in combination with the highly faulted reservoir makes inter-well correlations difficult (Knight et al. 1993). The igneous rocks represent an opportunity to constrain the evolution of the Embla oil field in time and to explore the relation of the local magmatism to the regional tectonic evolution of the North Sea. Unfortunately, the igneous rocks are highly clay- and carbonate-altered and do not retain their primary mineralogy. Many elements, including Large Ion Lithophile (LIL) elements such as $\mathrm{Rb}$, $\mathrm{Sr}$ and $\mathrm{K}$ are prone to mobilisation during alteration. Protolith age determinations and petrogenetic studies using isotopes of potentially mobile elements are thus problematic. In this study we therefore present geochemical data from cored mafic igneous rocks in the Embla oil field, and focus primarily on the relatively immobile High Field Strength (HFS) elements.

\section{Geological setting}

In the North Sea region crustal blocks of Laurentian, Baltican and Avalonian affinities were amalgamated to form Laurussia during the Caledonian orogeny. The suture zones represent weaknesses in the crust that have been repeatedly reactivated under the influence of shifting regional stress fields (Coward, 1995; Pharaoh, 1999; Scheck-Wenderoth and Lamarche, 2005). A ca. 375 Ma late Devonian magmatic event recorded on the northern and southern flanks of the Mid North Sea High, forming the easterly continuation of the Scottish Southern Uplands, has been taken as evidence for the existence of a late Devonian proto-Central Graben rift. The rift location hints at a relation to the Avalonia-Baltica suture zone (Lundmark et al., 2012; cf. Ziegler, 1990). In the early Carboniferous extension in the Variscan foreland (sensu lato) caused fault reactivation and development of 
fault-controlled basins in northern Britain, accompanied by mainly transitional to mildly alkaline 359-331 Ma Dinantian magmatism (ages for chronostratigraphic units throughout the paper given according to the timescale of Cohen et al., 2013, updated in 2017), which in the Scottish Midland Valley gave rise to up to $1000 \mathrm{~m}$ thick lava successions (Timmerman, 2004; Upton et al., 2004). In the 331-299 Ma Silesian alkaline to lamprophyric dike swarms were emplaced across northern Britain (Rock, 1983). The late Carboniferous alkaline dikes have been proposed to reflect incipient rifting signaling the start of the intense Stephanian - early Permian magmatism in north-western Europe (e.g. Lundmark et al., 2011). In northern Britain and the North Sea the Stephanian early Permian magmatism is manifested in numerous sub-alkaline 308-290 Ma quartz-dolerite dikes and sills (Monaghan and Pringle, 2004; Monaghan and Parrish, 2006). Related basalts in the Flora oil field, situated ca. $30 \mathrm{~km}$ to the southwest of the Embla oil field, yield an age of $299 \pm 3$ Ma (Heeremans et al., 2004), whereas stratigraphically lower basalt in the Flora oil field has a proposed age of ca. $310 \mathrm{Ma}$ (Martin et al., 2002). Early Permian volcanic rocks have also been encountered in the central North Sea in the Embla (this study), the Argyll/Ardmore (Robson, 1991) and the Auk (Trewin et al., 2003) oil fields. In the latter two the volcanic rocks are encountered above a lower Permian (?) unconformity and are overlain by lower Permian Auk Formation sandstones. Related voluminous 300-260 Ma magmatism in the Oslo Rift was initiated by $300 \pm 1 \mathrm{Ma}$ lamprophyre dikes and sills (Ramberg and Larsen, 1978; Corfu and Dahlgren, 2008), and preceded by local downwarping from ca. $310 \mathrm{Ma}$ (Olaussen et al., 1994). In northern Germany the event is characterized by extensive 303-290 Ma rhyolite magmatism (Breitkreuz et al., 2007). In south Sweden sparse lamprophyre ("kullaite") dikes are associated with a northwest trending subalkaline dolerite dike swarm dated to $289 \pm 4 \mathrm{Ma}$ (Klingspor, 1976; Welin, 1979) and $285 \pm 4$ Ma (Timmerman et al., 2009). The intense magmatism has been interpreted to reflect wrench tectonics associated with changing far-field stresses and the collapse of the Variscan orogeny (Ziegler and Dèzes, 2006; Timmerman et al., 2009), in combination with a $297 \pm 4$ Ma (Torsvik et al., 2008) mantle plume centred in the Skagerrak Sea (Ernst and Buchan, 1997). Along the northern flank of the Ringkøbing-Fyn High area, representing the eastern continuation of the Mid North Sea High, sills and extrusives (Karl Formation) have been proposed to reflect somewhat younger igneous activity based on K-Ar dating (280$260 \mathrm{Ma}$; Stemmerik et al., 2000). However, Heeremans et al. (2004) argue that the K-Ar ages likely reflect partial Ar-loss and suggest that the igneous rocks are related to the main ca. $300 \mathrm{Ma}$ magmatic event. In the North Sea region the magmatism gradually abated in the late early Permian, and with thermal equilibration of the crust a series of sag basins developed, including the Northern and Southern Permian basins, separated by the Mid North Sea High - Ringkøbing Fyn High (Ziegler and Dèzes, 2006). A new cycle of rifting in the late Permian Triassic reflects the overall transition from the assembling of Pangaea to its break-up (Gabrielsen et al., 1990; Heeremans et al., 2004). In the North Sea east-west directed extension and rifting along Caledonian tectonic lineaments severed the Mid North Sea High from the Ringkøbing Fyn High (Coward, 1995; Scheck-Wenderoth and Lamarche, 2005). The Triassic evolution of the rift basin was characterized by a near absence of volcanism (Ziegler, 1992). Renewed rifting in the mid Jurassic associated with plume activity and locally intense magmatism (Gabrielsen et al., 1990; Underhill and Partington, 1993; Odinsen et al., 2000) reached its apex in the North Sea in the late Jurassic - early Cretaceous (Rattey and Hayward, 1993). It was gradually superseded by rifting along the proto-Atlantic Ocean, and followed by thermal subsidence (Ziegler and Dèzes, 2006). Palaeogene dikes related to the opening of the Atlantic Ocean (British Tertiary Volcanic Province) have been mapped by 3D seismic south of the Mid North Sea High (Wall et al., 2010). On land the Palaeogene magmatism ranges from tholeiitic to alkaline basalt (Mattey et al., 1977). The Embla oil field comprises Palaeozoic, mainly terrestrial sediments, truncated and capped by Mesozoic marine sediments (Fig. 2; Knight et al., 1993). The deepest cored stratigraphic level consists of alkali rhyolites, one of which has given a zircon LA-ICPMS U-Pb age of $374 \pm 4 \mathrm{Ma}$ (Lundmark et al., 2012). The rhyolites are overlain by uncored claystone; palynological data from drill chips indicate a Givetian to Famennian age and reveal a limited marine influence (Knight et al., 1993). The claystone is overlain by coarse to fine grained siliciclastics that record transitions between alluvial fan/fluvial deposits and floodplain/lacustrine sediments. These terrestrial Palaeozoic sediments constitute the reservoir rocks of the Embla oil field. They are divided into a late Devonian and an early Permian section, separated by an inferred (uncored) unconformity. The sediments have been proposed to derive from late Devonian - early Carboniferous river systems originating in the Scottish and the Greenland Caledonides, and from recycling of sediments during early Permian inversion tectonics in Scotland, respectively (Lundmark et al., 2014). However, a general lack of suitable fossils in the oxidised continental red beds makes precise dating difficult. The reservoir section is unconformably overlain by late Jurassic and Cretaceous marine sediments (Knight et al., 1993). Mafic igneous rocks have been cored in four wells in the Embla oil field, where they are found in the late Devonian and the early Permian reservoir sections and in the late Jurassic cap rock section. All are highly clay- and carbonate-altered.

\section{Sample description}

Twelve samples were collected from eleven mafic igneous units in wells 2/7-21S, 2/7-26S, 2/7-25S and 2/7-23S of the Embla oil field (Table 1). 


\subsection{Well 2/7-21S}

A ca. $5 \mathrm{~m}$ thick interval of mafic porphyric rock (samples 20 and 22) cuts fine-grained sandstone at a high angle (Fig. 2). The sandstones on both sides of the mafic interval are paler and more quartz cemented than typical sandstone cored in the well, and brown goyazite mineralisations occur along fractures and permeable layers. The porphyry contains $<2 \mathrm{~mm}$ long lath-shaped plagioclase pseudomorphs, euhedral pyroxene pseudomorphs and rounded pseudomorphs that likely represent olivine (Fig. 3c). Both the phenocrysts and the finer grained (ca. $0.05 \mathrm{~mm}$ ) matrix are replaced by alteration minerals, mainly clay (illite and kaolin) and carbonates (dolomite and siderite). Minor chlorite, quartz, pyrite and a fine-grained rutile polymorph are also present throughout the rock. Needle-shaped apatite crystals are common, and may be primary. Dolomite cemented fractures with minor siderite and kaolin cut the rock, and are in their turn cut by siderite filled fractures.

\subsection{Well 2/7-26S}

Two main intervals of mafic igneous rocks are found in well 2/7-26S. The lower interval starts with a ca. $1.5 \mathrm{~m}$ thick porphyric unit above intensely hematite and carbonate altered mudstone. Upwards it is separated by an erosional (?) contact from a ca. $5 \mathrm{~m}$ thick porphyric unit that starts with a volcanic breccia and grade into locally flow banded porphyry. The interval is overlain by hematite and carbonate altered mudstone; mudstone ca. $0.5 \mathrm{~m}$ above the contact displays no hornfels alteration. A third, ca. $3 \mathrm{dm}$ thick aphanitic igneous unit is terminated upwards by a fault, separating it from a mudstone and a sandstone, and downwards by the end of the core section (Fig. 2). One sample was collected from each of the three units. The sample from the lowermost unit was collected a few centimetres below the contact to the overlying volcanic breccia (no. 64; Fig. 3a). It is finegrained $(<0.5 \mathrm{~mm})$ and highly altered. It is characterized by ubiquitous $\mathrm{mm}$-sized chloritic pseudomorphs after plagioclase micro-phenocrysts, and an illite and dolomite dominated matrix. White mica/illite with quartz lamellae are common, and form part of pseudomorphs. Up to $\mathrm{cm}$-sized dolomite and quartz filled irregular amygdales are common. The second sample (68) is porphyric with $<1.5 \mathrm{~cm}$ pseudomorphs after plagioclase and pyroxene set in a fine-grained matrix. Ca. $0.5 \mathrm{~mm}$ long elongated dark $\mathrm{TiO} 2$ crystals are common. The dominant alteration minerals are dolomite, illite and chlorite that replace both pseudomorphs and matrix minerals. The pseudomorphs locally define a flow banding. The two samples are interpreted to represent lava flows. One sample was collected from the ca. $3 \mathrm{dm}$ thick aphanitic igneous rock (no. 62; Fig. 3b). It is characterized by ca. $0.05 \mathrm{~mm}$ sized quartz grains embedded in claystone and carbonate-altered matrix. We interpret the interval as a mix of volcanic ash, silt and clay. The second main igneous interval is a ca. $10 \mathrm{~m}$ thick interval of fine to medium grained mafic rock (samples 66 and 67), which in its lower half grades into a monomict tectonic breccia. The immediate contacts to the surrounding sediments are not cored. Two internal contacts are distinguished by slight variations in grain size, texture and distribution of amygdales, hinting that the magmatic rocks are lava flows. Alternatively, the rocks may represent hypabyssal intrusions. The rock is similar to sample 68 in terms of texture and the presence of common $<1 \mathrm{~cm}$ long needle-like TiO2-crystals. Amygdales are mainly filled by dolomite and quartz. However, no flow banding is visible, and kaolin, illite and chlorite dominate the alteration assemblage at the expense of dolomite, which is mainly present in amygdales. The latter is commonly hematized, which gives the rock a red spotted appearance.

\subsection{Well $2 / 7-23$ S}

Well 2/7-23S penetrates the early Permian section of the Embla oil field. In the interval from $4490 \mathrm{~m}$ to $4545 \mathrm{~m}$ several thin mafic volcanic beds and volcaniclastic rocks are present along with fine-to pebbly coarse-grained sandstone and gravelly sandstones. Three volcanic beds, ranging in thickness from ca. $3 \mathrm{dm}$ to $1 \mathrm{~m}$, were sampled (samples 70, 71 and 72; Fig. 3d). All three samples have a felty kaoline and illite-dominated matrix. Ubiquitous scattered $\mathrm{TiO} 2$ crystals (typically $<10 \mu \mathrm{m}$ ) impart a brownish colour, likely aided by the presence of sparse goyazite grains. An irregular wavy texture defined by the orientation of kaolin-altered plagioclase microphenocrysts (and altered pumice/flattened glass shards?) define a flow banding. Sparse dolomite and kaolin filled $<2 \mathrm{~mm}$ irregular pseudomorphs are present. Dolomite and/or kaolin-filled amygdales locally make up nearly half of the rock. The dolomite is typically zoned, with some zones displaying preferential hematisation. Siderite filled fractures locally form extensive vein systems. These crosscut dolomite-kaoline altered pseudomorphs and amygdales. Other fractures are dominated by quartz and kaolin.

\subsection{Well $2 / 7-25 S$}

Well 2/7-25S includes core from the reservoir cap rocks. A ca. $15 \mathrm{~m}$ thick interval of faulted, brecciated and calcite-veined mafic volcanic and volcaniclastic beds are present within a sequence of marine sandstones (turbidites?) and mudstones. The interval has been dated to Kimmeridgian-Tithonian by palynological methods (ConocoPhillips, personal communication 2010). Two volcanic units were sampled (samples 65 and 69). These are porphyric with $<1.5 \mathrm{~mm}$ albite/calcite altered plagioclase laths in a fine grained matrix. The plagioclase locally makes up $50 \%$ of the rock, and defines flow banding together with calcite filled amygdals. Sparse clay 
and calcite-altered pyroxene pseudomorphs are also present. The rocks are highly altered and consist primarily of albite, calcite, pyrite and clays.

\section{Geochemistry}

\subsection{Analytical techniques}

Twelve igneous rock samples from the Embla oil field were analysed for major and trace elements, along with two samples of late Devonian Embla shale (Table 1). Care was taken to avoid fractures where possible. Major elements, Sc, Be, V, Sr and Ba were determined by wholerock lithium metaborate/tetraborate fusion (FUS) and inductively coupled plasma-atomic emission spectrometry (ICP-AES), remaining analysed trace elements were determined by FUS inductively coupled plasma mass spectrometry (ICPMS). The analyses were done as part of the 4Lithoresearch package at Activation Laboratories Ltd, Ancaster, Ontario, Canada. The results are shown in Table 2. The data are given in excel-format and with detection limits in Appendix 1.

\subsection{Results}

Selected major and trace element data from the igneous rocks analysed in this study are shown in Figs. 4 and 5. The data are normalized to primary mantle after McDonough and Sun (1995). To account for high volatile contents in the samples the data are recalculated to $100 \%$ dry. The absolute and relative element abundances yield geochemical signatures that fall into three groups, a) samples from well 2/7-26S, b) samples from well 2/7$23 \mathrm{~S}$ and 2/7-21S; and c) samples from well 2/7-25S. These are henceforth referred to as groups A, B and C. Since sample 62 is interpreted as a mix between volcanic ash and sediments it is henceforth not included in the discussion of the igneous geochemical data unless specifically stated. However, the data are plotted in all figures for comparison. The loss on ignition (LOI) ranges from 12 to $23 \%$ in the igneous samples, reflecting the extensive clay and carbonate alteration of the rocks. The $\mathrm{SiO} 2$ content of the analysed igneous samples ranges from 34 to $56 \%$ (100\% dry). Increasing LOI is typically accompanied by decreasing $\mathrm{SiO} 2$ and LIL elements, and increasing $\mathrm{CaO}$, and in groups $\mathrm{A}$ and $\mathrm{B}$ increasing $\mathrm{MgO}$ contents (Fig. 5). A relatively high variability in group A is mainly due to samples 62 and 64 (Figs. 4 and 5). On a 100\% dry basis Group A yields relatively high $\mathrm{SiO} 2$ (43-63\%) and low Al2O3 (15-18\%) contents. Group B tends to have relatively low $\mathrm{SiO} 2(34-42 \%)$, high $\mathrm{Al} 2 \mathrm{O} 3$ (23-30\%) and high LIL and HFS element concentrations, along with high LOI. Group C, on the other hand, while intermediate between groups A and B in $\mathrm{SiO} 2$ (40-43\%) and Al2O3 (14-19\%) contents, yields distinctly higher $\mathrm{Na} 2 \mathrm{O}(4.2-4.5 \%)$ and also yields low total sums (93-97\%) suggesting loss of elements such as $\mathrm{S}$ or $\mathrm{Li}$ (which are not scanned for in the ActLabs 4Lithoresearch package). Significantly, there are systematic differences in the HFS element signatures of groups A, B and C. The Zr/Hf ratios of groups A (33.8-35.9), B (36.8-42.6) and $\mathrm{C}(43.6-48.2)$ are distinct. The $\mathrm{Nb}$ /Ta ratio separates group A (14.1-15.1) from group C (15.215.4), both of which overlap with data from group B (12.5-16.1). The (La/Yb)N distinguishes group B (7.2-20.8) from groups A (1.6-5.9) and C (3.4-4.5).

\section{Discussion}

\subsection{Significance of the three geochemical groups}

The three groups of volcanic rocks that emerge from the geochemical data correspond well to the stratigraphic positions of the samples. Thus, the samples making up group A are found in the late Devonian sequence of the Embla reservoir, including both extrusive rocks and rocks of uncertain extrusive or intrusive origins. Samples forming group B comprise extrusive rocks in the early Permian reservoir sequence, and samples from a dike in the late Devonian section. Group C consists of two analyses from extrusive rocks in the late Jurassic cap rock section. We interpret the groups to represent three distinct magmatic events that are constrained by their stratigraphic positions to be of late Devonian, early Permian and late Jurassic ages, respectively. The mafic igneous interval in well 2/7-26S (samples 66, 67) was difficult to classify as volcanic or intrusive based on petrographic and contact relations; it is chemically related to extrusive rocks a few tens of metres below in the stratigraphy and hence interpreted to represent volcanic (or shallow subvolcanic) rocks. The mafic igneous body in the late Devonian - early Carboniferous section in well 2/7-21S interpreted as a dike from the observed contact relations is chemically related to the early Permian volcanic rocks, and hence likely represents an early Permian feeder dike. Alternatively, but in our view less likely, the dike could represent a fourth magmatic event, a scenario discussed below.

\subsection{Alteration: patterns and origins}

The replacement of magmatic minerals in the mafic igneous rocks by mainly clays, carbonates and oxides indicate alteration under near surface conditions. In the Palaeozoic rocks (groups A and B) the primary mineral phases are replaced by clay minerals (illite, kaolin and chlorite) and dolomite, with minor Fe-, $\mathrm{Ca}-$, and $\mathrm{Mn}-$ 
bearing carbonates occurring primarily as overgrowths on dolomite and in fractures crosscutting the dolomite. The rocks are commonly oxidised, causing locally intense hematite alteration of the dolomite. The dike in 2/7$21 \mathrm{~S}$ is an exception in that it lacks hematite. This suggests that although alteration took place near the surface, the depth was sufficient to prevent the presence of oxidising water. Pyrite in the extrusive rocks is mainly tied to fractures and faults. Similar alteration documented in the stratigraphically lower alkali rhyolites has been proposed to reflect a combination of early diagenesis and weathering (although low temperature hydrothermal alteration could not be ruled out; Lundmark et al., 2012). The samples of group C (late Jurassic) are also highly altered, but here the feldspar is primarily replaced by albite, and the extensive carbonate alteration is nearly exclusively calcitic. The dolomite alteration observed in the Palaeozoic rocks is absent. Ubiquitous pyrite is scattered throughout the rocks, testifying to reducing conditions during alteration. The mineralogy translates into the highest $\mathrm{Na} 2 \mathrm{O}$ (ca. $4.5 \%$ ) and $\mathrm{CaO}$ contents (13-22\%) of the analysed rocks (100\% dry). In combination with the marine setting of the volcanism this indicates that the volcanic rocks have undergone spilitisation. The observed alteration patterns demonstrate that dolomite/kaolin alteration of the Palaeozoic sediments is pre-late Jurassic. The presence of hematite over a wide depth range in the Embla oil field is suggestive of syndepositional Palaeozoic weathering, potentially in concert with deep weathering related to major unconformities (cf. Fig. 2). The intense clay- and dolomite alteration of the early Permian dike in conjunction with absence of hematite, despite hematite being present in stratigraphically lower and higher igneous rocks, is most easily reconcilable with deep weathering.

\subsection{Rock classification}

Chemical changes accompanying the mineralogical changes described above are illustrated in Fig. 5. Addition of volatile species $(\mathrm{H} 2 \mathrm{O}, \mathrm{CO} 2)$ during clay and carbonate alteration is evident in the high LOI values $(<24 \%)$. A concomitant increase in $\mathrm{CaO}$ and $\mathrm{LOI}$ indicates that $\mathrm{CaO}$ also was added to the rocks during alteration. The same pattern holds for $\mathrm{MgO}$ in the dolomitized Palaeozoic rocks, whereas decreasing $\mathrm{MgO}$ in the spilitised early Jurassic rocks suggest loss of $\mathrm{MgO}$ during alteration. Similarly, decreasing $\mathrm{SiO} 2$ and $\mathrm{K} 2 \mathrm{O}$ with increasing LOI indicate leaching during alteration. The TiO2 content of the rocks, on the other hand, appears to be uncorrelated with the LOI, suggesting that $\mathrm{TiO} 2$ remained largely immobile (on sample scale) during alteration. The apparent immobility of Ti suggests that HFS elements, in contrast to the more mobile major elements, may be useful for rock classification. Several classification and discrimination diagrams have been developed for altered igneous rocks based on HFS elements (e.g. Winchester and Floyd, 1977; Wood, 1980; Meschede 1986). The degree of mobility of the HFS elements in the present study is not easily tested due to the limited number of analyses. However, the fact that HFS elements in associated rocks form coherent patterns supports a low degree of mobility at the sample scale (cf. Figs. 4 and 6-8). Also, a previous study of altered alkali rhyolites in the Embla oil field demonstrated that despite high LIL element and LREE mobility, the overall HFS element mobility was low (Lundmark et al., 2012). Winchester and Floyd (1977) proposed the use of the $\mathrm{Zr} / \mathrm{TiO} 2$ and $\mathrm{Nb} / \mathrm{Y}$ ratios to identify protoliths of altered volcanic rocks. All the samples in this study yield low $\mathrm{Zr} / \mathrm{TiO} 2$ values (Fig. 6a) consistent with basaltic compositions and a low degree of magmatic differentiation. Sample 62, interpreted to reflect a mix of volcanic and siliciclastic sediments, yields an elevated $\mathrm{Zr} / \mathrm{TiO} 2$ ratio consistent with crustal contamination (and strictly speaking falls within the $\mathrm{Zr} / \mathrm{TiO} 2$ range of basaltic andesite; Pearce, 1996). On the $\mathrm{Nb} / \mathrm{Y}$ axis the samples display considerable variation, indicating different degrees of alkalinity. Three of the late Devonian samples (group A) plot as transitional basalts, i.e., across the divide between the subalkaline basalt field and the alkali basalt field (and within $\mathrm{Nb} / \mathrm{Y}$ ratios from 0.5 to 1 , hence transitional sensu Pearce and Cann, 1973). One analysis (no. 64) plots well into the subalkaline field. This sample yields elevated Ni and Co concentrations, suggestive of some degree of olivine accumulation (e.g. Pearce, 1996). This should have a limited impact on HFS element ratios, since these elements typically are highly incompatible in olivine. The sample also displays the highest degree of alteration of the late Devonian samples (cf. Fig. 4), perhaps as a result of a high content of olivine in the protolith. A slightly anomalous trace element signature, e.g., low $\mathrm{Nb}$, Ta and Th, and elevated LREE, may reflect olivine accumulation, the extensive alteration, some degree of protolith heterogeneity, crustal contamination, or, most likely, some combination thereof. Sample 62 yields relatively high $\mathrm{SiO} 2, \mathrm{~A} 12 \mathrm{O} 3$ and $\mathrm{K} 2 \mathrm{O}$, and low $\mathrm{CaO}, \mathrm{MgO}, \mathrm{P} 2 \mathrm{O} 5$ and $\mathrm{TiO} 2$ (Fig. 5). Furthermore, in Fig. 4 the HFS elements ( Th, Zr, Hf, Ti, Nb, Ta) tend to be intermediate between the other analyses from group A and data from two late Devonian Embla shale samples (samples 40 and 41; Table 2). This is in accordance with the inference that sample 62 represents a mix of volcanic and siliciclastic sediments. The early Permian samples (group B) plot as alkali basalts, with one analysis from the dike plotting in the foidite field. This could reflect minor Y mobility, which has affected the alkali rhyolites stratigraphically below the dike (Lundmark et al., 2012). However, whereas high element mobility in the alkali rhyolites extended from elements with a low ionic potential to include the middle REEs (Sm-Ho), this does not appear to be the case in this study; the trends and absolute levels of REEs in Fig. 4 are consistent with the HFS element classification. The high alkalinity is therefore interpreted to reflect the protolith chemistry. The higher element mobility in the alkali rhyolites compared to the basalts may reflect primary mineralogical differences, or the effects of deuteric alteration affecting the rhyolites (cf. 
Lundmark et al., 2012). The late Jurassic samples (group C) plot in the subalkaline part of the diagram. The $\mathrm{Nb} / \mathrm{Y}$ ratio can also be plotted against the $\mathrm{Zr} / \mathrm{P} 2 \mathrm{O} 5$ ratio to specifically distinguish tholeiitic from alkaline basalts (Fig. 6b; Floyd and Winchester, 1975). The late Devonian samples plot in the tholeiites section of the diagram, near the boundary to alkaline compositions (except for analysis 64 that yields a distinct tholeiitic signature reflecting its low $\mathrm{Nb}$ content); textural evidence for olivine phenocrysts, further supported by relatively high $\mathrm{Ni}$ contents in the analysed samples (ranging from 177 to $387 \mathrm{ppm}$ recalculated to $100 \%$ dry) indicate that the rocks are transitional olivine tholeiite basalts. The early Permian samples yield a typical alkaline trend with variable $\mathrm{Nb} / \mathrm{Y}$ and low $\mathrm{Zr} / \mathrm{P} 2 \mathrm{O} 5$, whereas the late Jurassic samples plot as tholeiitic basalts (see Floyd and Winchester, 1975 for a discussion of the potential effects of spilitisation).

\subsection{LIL element mobility and the nature of the early Permian rocks}

The early Permian samples (group B) yield comparatively high LOI values, and distinctly low $\mathrm{SiO} 2$ and high $\mathrm{A} 12 \mathrm{O} 3$ contents for comparable LOI. We interpret this to partly reflect compositional differences inherited from the protoliths, whereas the high $\mathrm{Al} 2 \mathrm{O} 3$ is suggestive of some plagioclase accumulation. The comparatively high content of LIL elements in the early Permian rocks also matches the alkaline HFS element signature, indicating partial retention of mobile elements at the sample scale despite the extensive alteration. The Sr content in the dike (samples 20,22) offers an example of the scale of LIL element mobility. The dike has a lower $\mathrm{Sr}$ content than the related extrusive rocks (350-400 ppm vs. 570-2120 ppm for 100\% dry). Conversely, the sandstone adjacent to the mafic dike hosts conspicuous brown goyazite mineralisations along fractures and high permeability zones. The inference that the $\mathrm{Sr}$ in the goyazite originated in the dike indicates that $\mathrm{Sr}$ was mobile in fractures and high permeability layers at $\mathrm{dm}$ to meter scale. The goyazite-mineralised fractures in the sandstone are not invaded by igneous rock, indicating that fracturing and Sr mobilization post-date magma emplacement. The high inferred primary volatile, Al2O3-, LIL- and HFS element contents are compatible with highly alkaline protoliths reminiscent of lamprophyric rocks. However, lamprophyres are typically hypabyssal and rarely extrusive, and lack feldspar phenocrysts (Rock, 1987). The early Permian Embla rocks therefore appear to have fallen short of true lamprophyres. A Palaeocene K-Ar age has been reported for the dike. The age was suggested to be either unreliable or dating hydrothermal alteration since the interval was interpreted as extrusive, and hence Palaeozoic in age (Knight et al., 1993). Its re-interpretation as a dike re-opens the question of the validity of the K-Ar age, particularly since Palaeocene magmatism is known south of the Mid North Sea High (Wall et al., 2010). Though a Tertiary age cannot be conclusively ruled out, we interpret the dike to be early Permian and regard the K-Ar age as suspect given a) the uncertainties associated with clay K-Ar analyses to determine a magmatic protolith age, b) the geochemical similarities between the dike and the early Permian extrusives in this study, and c) the alteration pattern of the dike which appears to fit with the other Palaeozoic igneous rocks (apart from the absence of hematite as discussed in an earlier section).

\subsection{HFS element signatures and tectonic setting of the Embla magmatism}

The nature and origin of the analysed rocks can be further constrained by the HFS element signatures of the rocks (Pearce, 1996; see Li et al. (2015) for a discussion on the limitations of this approach). A number of HFS element diagrams have been proposed to discriminate between different parental magmas and tectonic settings. Two diagrams commonly used are the Hf-Th-Ta diagram of Wood (1980) and the Nb-Zr-Y diagram of Meschede (1986). The late Devonian rocks (group A) plot as within-plate basalts (with the exception of the anomalous sample 64, which plots in the MORB field in both diagrams), the early Permian rocks (group B) plot as alkaline within-plate basalts, and the late Jurassic rocks (group C) plot as within-plate tholeiites (Fig. 7a) and just outside the within-plate tholeiite field in the volcanic arc field (Fig. 7b). It is illustrative to compare the new data from this study to previously published data from early Permian and late Jurassic basaltic rocks in the North Sea region. Latin et al. (1990) used the $\mathrm{Ce} / \mathrm{Y}$ and $\mathrm{Zr} / \mathrm{Nb}$ ratios as proxies for the degree of melting and the source composition, respectively, and in so doing delineated some HFS element characteristics of the magmatic groups (Fig. 8a and b). The data included by Latin et al. (1990) were restricted to analyses with $\mathrm{MgO}>4 \%$. In the present study $\mathrm{MgO}$ mobility precludes its use to screen for crustal contamination, and Ce immobility is primarily deduced from the overall REE signatures (and may not apply to the highly altered sample 64; cf. Fig. 4). However, the general absence of pronounced negative $\mathrm{Nb}, \mathrm{P}$ and $\mathrm{Ti}$ anomalies in the analysed igneous rocks suggest that crustal contamination is restricted (cf. for example Bensalah et al., 2013). Such anomalies are distinct in the two analyses of late Devonian Embla shales, and in the case of P, in sample 62 (Fig. 4a). Using sample 62, a mix of volcanic and siliciclastic sediments, and the data from Embla shales as proxies for crustal contamination provide additional arguments against crustal contamination. Sample 62 yields a $\mathrm{Zr} / \mathrm{TiO} 2 \mathrm{ratio}$ of 0.018 (Fig. 6a), and the Embla shale analyses yield even higher ratios of 0.046 and 0.075 (sediments typically have high $\mathrm{Zr} / \mathrm{TiO} 2-$ ratios compatible with those of evolved volcanic rocks; Pearce, 1996). The remaining analyses of igneous rocks from the Embla field in this study yield low $\mathrm{Zr} / \mathrm{TiO} 2$ ratios consistent with negligible crustal contamination (Fig. 6a). Furthermore, in the Wood diagram (Fig. 7a) sample 62 plot in the lower left corner of the volcanic arc field along with the analysed Embla shales (not shown), suggesting a crustal 
contamination trend that does not seem to affect the other analysed rocks in this study. In Fig. 8a the late Devonian Embla rocks plot over a wide $\mathrm{Zr} / \mathrm{Nb}$ range near the melting curves for spinel lherzolite, hinting at variable degrees of melting in the spinel zone. The early Permian Embla data plot with the Scottish alkaline Permo-Carboniferous rocks (Upton et al., 2004), and are distinctly different from the Permo-Carboniferous quartz dolerites and the geographically nearby $299 \pm 3$ Ma Flora oil field basalt (Heeremans et al., 2004). The data from the Permian rocks in the Embla field are compatible with low degree melts in a zone reaching from the garnet to the spinel stability field (cf. Upton et al., 2004). Steepening REEN slopes accompany the increasing $\mathrm{Ce} / \mathrm{Y}$ ratios in the samples, lending support to this interpretation. Published data on Jurassic magmatism in the North Sea region illustrate the alkaline low degree partial melt character of these rocks (Fig. 8b). In contrast, the Jurassic samples from the Embla oil field yield high $\mathrm{Zr} / \mathrm{Nb}$ ratios compatible with distinctly higher degrees of melting.

\subsection{Regional context and implications of the Embla magmatism}

The volcanism in the Embla oil field can be linked in space and time to the tectono-magmatic evolution of the North Sea region. This offers the opportunity to further our understanding of both the evolution of the Embla oil field and the regional events.

\subsubsection{Late Devonian transitional basalt (group A)}

The extrusive and subvolcanic (?) transitional within-plate basalts in 2/7-26S are stratigraphically located within a mainly terrestrial sedimentary sequence interpreted as late Devonian (to early Carboniferous), situated stratigraphically above ca. 375 Ma Frasnian alkali rhyolites. The apparent association in space and time of the basalts and the rhyolites suggest that they represent a bimodal suite, potentially genetically linked through assimilation - fractional crystallization processes. An argument against such a genetic link is provided by the markedly different $\mathrm{Zr} / \mathrm{Hf}$ ratios in the mafic rocks (34-36) and the rhyolites (ca. 20, with one (sub-) volcanic unit yielding ca. 32; Lundmark et al., 2012). The low ratios in the rhyolites could, on the other hand, reflect chemical complexation and mobility of HFS elements in highly evolved magmatic systems (Irber, 1999), an interpretation that finds some support in the deuteric alteration described by Lundmark et al. (2012), involving e.g. crystallisation of interstitial zircon. Our preferred interpretation is that the basalts represent the mafic component of late Devonian bimodal magmatism on the Mid North Sea High, potentially related to extension in a protoCentral Graben, as suggested by Lundmark et al. (2012). Alternatively, the transitional basalts may be significantly younger than the underlying alkali rhyolite, and linked with 359-347 Ma Tournasian sub-alkaline to alkaline volcanism in the Southern Uplands, known from the Birrenswark and Kelso Volcanic Formations, and Eildon Hill (the latter dated to 352.5 $\pm 1.4 \mathrm{Ma}$ by Monaghan and Pringle, 2004), or younger 359-331 Ma Tournasian-Visean, mainly transitional basalts in the Midland Valley Complex (Upton et al., 2004).

\subsubsection{Early Permian alkali basalt (group B)}

The alkaline within-plate basalts in the Embla oil field are stratigraphically located in a section assigned an early Permian age based on palaeomagnetic data (cf. Lundmark et al., 2014). In the North Sea region incipient rifting and associated ca. $300 \mathrm{Ma}$ alkaline magmatism (Corfu and Dahlgren, 2008) was followed by a 301-295 Ma (Monaghan and Pringle, 2004) tholeiitic magmatic flare up and emplacement of large volumes of quartz dolerite dikes and sills (Upton et al., 2004). These include the $308 \pm 5$ Ma quartz dolerites in the Midland Valley sill complex, the ca. 300 Ma Whin Sill Complex in northern England (Monaghan and Parrish, 2006) and $299 \pm 3$ Ma basalts in the Flora oil field (Heeremans et al., 2004). In addition, 298-292 Ma alkaline magmatism erupted in the Midland Valley (Monaghan and Parrish, 2006), and alkaline lavas interpreted to fall within this age span are also known from the Southern Uplands (Upton et al., 2004, and references therein). Altered basalt in the Argyll oil field (Robson, 1991) and leucite-nepheline basalt in the Auk oil field (Trewin et al. 1991) mark the base of Rotliegend deposits on top of Devonian sediments, and are potential correlatives of the early Permian volcanic rocks in this study. We propose that the alkaline rocks in the Embla oil field are associated with this late Carboniferous - early Permian event. The alkaline character of the volcanic rocks in the Embla oil field suggests that the rocks most likely belong either to the ca. 300 Ma incipient rift stage, or the 298-292 Ma alkaline phase documented in southern Scotland. The latter is more easily reconciled with early Permian palaeomagnetic ages in the Embla oil field (cf. Lundmark et al., 2014).

\subsubsection{Late Jurassic tholeiitic basalt (group C)}

The tholeiitic within-plate basalts in the Embla oil field are interleaved with Kimmeridgian-Tithonian (157.3145.0 Ma) sediments that truncate the Palaeozoic reservoir rocks, and which in turn are truncated by the Base Cretaceous Unconformity complex (Fig. 2; Knight et al., 1993). Mid and late Jurassic uplift, tripartite rifting and volcanism in the North Sea indicate that the region was underlain by a mantel plume. Regional Aalenian erosion of the dome created the Mid-Cimmerian unconformity and was followed by the formation of the Moray Firth, Viking and Central Graben triple rift system (Underhill and Partington, 1993; Davies et al. 2001, Fig. 9). The 
Jurassic unconformity developed in the Embla oil field may reflect regional uplift in response to the mid Jurassic mantle plume and the ensuing rifting in the late Jurassic (Pedersen et al., 2007; Ohm et al., 2012). The triple rift system appears to have undergone sequential extension: east - west in the 168-163 Ma Bathonian-Callovian, northwest - southeast in the 163-157 Ma Oxfordian, and northeast - southwest in the late 157-145 Ma Kimmeridgian - Tithonian. The rotation of the stress field may reflect changing far-field stresses (Davies et al., 2001). The Forties Volcanic Province is centred on the triple junction and consists of four volcanic centres (Smith and Ritchie, 1993) that make up the Rattray and the Ron Volcanic Members in the Pentland Formation. The igneous rocks yield a wide range of radiometric ages, but the stratigraphic position of extrusive lavas constrain the magmatism to Bathonian to Callovian ages (Smith and Ritchie, 1993). The central parts of the Forties Volcanic Province are dominated by subaerial porphyric alkali olivine basalt (Fall et al., 1982). The basalts and tuffs locally reach thicknesses of $<2 \mathrm{~km}$. The more distal and less voluminous magmatism of the Ron Volcanic Member, along with related magmatism in the Egersund Basin and the Netherlands, is characterized by more undersaturated (ultrapotassic or nephelinitic) compositions, and are commonly lamprophyric (Latin and Waters, 1992). In Scania alkaline volcanic necks yield Ar-Ar ages from 191 to $110 \mathrm{Ma}$ and are interpreted to partly relate to the mid Jurassic Forties Volcanic Province (Bergelin et al., 2011). In contrast, a purportedly subalkaline tholeiitic tuff bed has been described from the Bajocian Ness Formation in the Statfjord oil field (Fig. 9; Malm et al., 1979). However, the reported major element data largely overlap with the typically alkaline (Latin and Waters, 1992) Rattray Volcanic Member signature. The tholeiitic basalts in the Embla oil field differ from the volcanism in the Forties Volcanic Province in several respects. The Embla volcanism a) occupies a higher stratigraphic position, b) yields a tholeiitic signature and c) erupted in a marine setting. Whereas the alkaline Forties Volcanic Province appears to be associated with uplift and the first east - west dominated rift phase that pre-dates the main period of extension (Rattey and Hayward, 1993; Hendrie et al. 1993), the Embla oil field tholeiitic basalts overlap in time with the third, late Kimmeridgian-Tithonian rift phase defined by Davies et al. (2001). This rift phase constitutes the main extensional event in the Central Graben (Rattey and Hayward, 1993), and ended with the transition to the postrift phase and the associated formation of the "late-Cimmerian" Base Cretaceous Unconformity complex (Kyrkjebø et al., 2004). The tholeiitic composition, sub-horizontal REE patterns, low HFS element concentrations and the HFS element signatures of the Embla rocks indicate higher degrees of melting closer to the Earth's surface than in the previously reported alkaline mid Jurassic magmatism (Fig. 8b). This appears to match the increase in extension in the late-Kimmeridgian-Tithonian in the Central Graben. We therefore interpret the tholeiitic basalts in the Embla oil field to be associated with the main late Kimmeridgian-Tithonian rifting in the Central Graben. This suggests that the Embla tholeiitic basalts form part of a hitherto unrecognized volcanic province in the Central Graben that may have been partly removed by formation of the Base Cretaceous Unconformity complex.

\section{Conclusions}

Despite a high degree of near-surface clay- and carbonate-alteration the HFS elements in eleven mafic volcanic units in the Embla oil field have remained largely immobile at the sample scale, allowing classification, grouping and tectonic interpretation of the igneous rocks. Three magmatic events are recognized in the Embla oil field. A late Devonian event comprises bimodal transitional basalt and alkali rhyolite associated with the formation of a proto-Central Graben. An early Permian event comprises in- and extrusive alkaline basalts representing low degree melts. We suggest that the basalts are a local expression of alkaline magmatism associated with the late Carboniferous - early Permian magmatic flare up. It may be part of the ca. 300 Ma lamprophyric magmatism preceding the main ca. 297 Ma tholeiitic igneous activity, or part of the 298-292 Ma alkaline magmatism documented in the Midland Valley and the Southern Uplands. A late Jurassic event led to the eruption of submarine (spilitised) tholeiitic basalts. We propose that the volcanism represents the magmatic component of the main late Kimmeridgian-Tithonian rift phase in the Central Graben, potentially representing the remains of a larger, hitherto undocumented volcanic province in the Central Graben.

\section{Acknowledgment}

This study was financed by ConocoPhillips Norway, who also made available core samples and geochemical data. The Norwegian Petroleum Directorate provided material for samples 70, 71 and 72. Elin Kallesson contributed on sedimentological issues. Håkon Austrheim is acknowledged for drawing the first author's attention to the goyazite mineralisations in well 2/7-21S. Else-Ragnhild Neumann provided valuable comments on an earlier version of the manuscript. João Mata and Nasrrddine Youbi are acknowledged for their reviews and constructive input.

\section{Appendix A. Supplementary data}

Supplementary data related to this article can be found at http://dx.doi.org/10.1016/j.marpetgeo.2017.11.018. 


\section{References}

Altermann, W., Nelson, D.R., 1998. Sedimentation rates, basin analysis and regional correlation of three Neoarchean and Paleoproterozoic subbasins of the Kaapvaal craton as implied by precise SHRIMP U-Pb zircon ages from volcanic sediments. J. Sediment. Geol. 120, 225-256.

Bensalah, M.K., Youbi, N., Mata, J., Madeira, J., Martins, L., El Hachimi, H., Bertrand, H., Marzoli, A., Bellieni, G., Doblas, M., Font, E., 2013. The Jurassic-Cretaceous basaltic magmatism of the Oued El-Abid syncline (High Atlas, Morocco): physical volcanology, geochemistry and geodynamic implications. J. Afr. Earth Sci. 81, 60-81.

Bergelin, I., Obst, K., Söderlund, U., Larsson, K., Johansson, L., 2010. Mesozoic rift magmatism in the North Sea region: 40Ar/39Ar geochronology of Scanian basalts and geochemical constraints. Int. J. Earth Sci. 100, 787-804.

Breitkreuz, C., Kennedy, A., Geißler, M., Ehling, B.-C., Kopp, J., Muszynski, A., Protas, A., Stouge, S., 2007. Far Eastern Avalonia: its chronostratigraphic structure revealed by SHRIMP zircon ages from Upper Carboniferous to Lower Permian volcanic rocks (drill cores from Germany, Poland and Denmark). Geol. Soc. Am. Special Pap. 423, 173-190.

Cohen, K.M., Finney, S.C., Gibbard, P.L., Fan, J.-X., 2013. The ICS international chronostratigraphic chart. Episodes 36, 199-204 updated 2017.

Corfu, F., Dahlgren, S., 2008. Pervoskite U-Pb ages and the Pb isotopic composition of alkaline volcanism initiating the Permo-Carboniferous Oslo Rift. Earth Planet. Sci. Lett. 265, 256-269.

Coward, M.P., 1995. Structural and tectonic setting of the Permo-Triassic basins of northwest Europe. Geol. Soc. Lond. Spec. Publ. 1995, 7-39.

Coward, M.P., Dewey, J.F., Hempton, M., Holdroyd, J., 2003. Tectonic evolution. In: Evans, D., Graham, C., Armour, A., Bathurst, P. (Eds.), The Millenium Atlas: Petroleum Geology of the Central and Northern North Sea. Geological Society, London, pp. 17-33.

Davies, R.J., Turner, J.D., Underhill, J.R., 2001. Sequential dip-slip fault movement during rifting: a new model for the evolution of the Jurassic trilete North Sea rift system. Pet. Geosci. 7, 371-388.

Ernst, R., Buchan, K.L., 1997. Giant radiating dyke swarms: their use in identifying pre-Mesozoic large igneous provinces and mantle plumes. In: Mahoney, J.J., Coffin, M.F. (Eds.), Large Igneous Provinces: Continental, Oceanic and Planetary Flood Volcanism. Geophysical Monograph, vol. 100. American Geophysical Union, pp. 297-333.

Fall, H.G., Gibb, F.G.F., Kanaris-Sotiriou, R., 1982. Jurassic volcanic rocks of the northern North Sea. J. Geol. Soc. Lond. 139, 277-292.

Floyd, P.A., Winchester, J.A., 1975. Magma type and tectonic setting discrimination using immobile elements. Earth Planet. Sci. Lett. 27, 211-218.

Gabrielsen, R.H., Færseth, R.B., Steel, R.J., Idil, S., Kløvjan, O.S., 1990. Architectural styles of basin fill in the northern Viking Graben. In: Blundell, D.J., Gibbs, A.D. (Eds.), Tectonic Evolution of the North Sea Rifts. Clarendon Press, Oxford, pp. 158-179.

Heeremans, M., Timmerman, M.J., Kirstein, L.A., Faleide, J.I., 2004. New constraints on the timing of late Carboniferous-early Permian volcanism in the central North Sea. Geol. Soc. Lond. Spec. Publ. 223, $177-193$.

Hendrie, D.B., Kusznir, N.J., Hunter, R.H., 1993. Jurassic extension estimates for the North Sea 'triple junction' from flexural backstripping: implications for decompression melting models. Earth Planet Sci. Lett. 116, 113127.

Irber, W., 1999. The lanthanide tetrad effect and its correlation with $\mathrm{K} / \mathrm{Rb}, \mathrm{Eu} / \mathrm{Eu} *, \mathrm{Sr} / \mathrm{Eu}, \mathrm{Y} / \mathrm{Ho}$, and $\mathrm{Zr} / \mathrm{Hf}$ of evolving peraluminous granite suites. Geochimica Cosmochimica Acta 63, 489-508.

Kirstein, L.A., Davies, G.R., Heeremans, M., 2006. The petrogenesis of Carboniferous-Permian dyke and sill intrusions across northern Europe. Contributions Mineralogy Petrology 152, 721-742. http://dx.doi.org/10.1007/s00410-006-0129-9.

Klingspor, I., 1976. Radiometic age-determination of basalts, dolerites and related syenite in Skåne, southern Sweden. Geol. Föreningens i Stockh. Förhandlingar 98, 195-216.

Knight, I.A., Allen, L.R., Coipel, J., Jacobs, L., Scanlan, M.J., 1993. The Embla field. In: Parker, J.R. (Ed.), Petroleum Geology of Northwest Europe: Proceedings of the $4^{\text {th }}$ Conference. Geological Society, London, pp. $1433-1444$.

Kyrkjebø, R., Gabrielsen, R.H., Faleide, J.I., 2004. Unconformities related to Jurassic-cretaceous syn/post-rift transition of the northern North Sea. J. Geol. Soc. Lond. 161, 1-17.

Latin, D.M., Dixon, J.E., White, N., Fitton, J.G., 1990. Mesozoic magmatic activity in the North Sea Basin: implications for stretching history. Geol. Soc. Lond. Spec. Publ. 55, $207-227$.

Latin, D., Waters, F.G., 1992. Basaltic magmatism in the North Sea and its relationship to lithospheric extension. Tectonophysics 208, 77-90.

Li, C., Arndt, N.T., Tang, Q., Ripley, E.M., 2015. Trace element indiscrimination diagrams. Lithos 232, $76-83$. 
Lundmark, A.M., Gabrielsen, R.H., Brown, J.F., 2011. Zircon U-Pb age for the Orkney lamprophyre dyke swarm, Scotland, and relations to Permo-Carboniferous magmatism in north-western Europe. J. Geol. Soc. Lond. 168, 1233-1236.

Lundmark, A.M., Gabrielsen, R.H., Austrheim, H., Flaat, K., Strand, T., Ohm, S.E., 2012. Late Devonian rifting in the central North Sea: evidence from altered felsic volcanic rocks in the Embla oil field. Mar. Petroleum Geol. 29, 204-218.

Lundmark, A.M., Bue, E.P., Gabrielsen, R.H., Flaat, K., Strand, T., Ohm, S.E., 2014. Provenance of late Palaeozoic terrestrial sediments on the northern flank of the Mid North Sea High: detrital zircon geochronology and rutile geochemical constraints. Geol. Soc. Lond. Spec. Publ. 386, 243-259.

Malm, O.A., Furnes, H., Bjørlykke, K., 1979. Volcaniclastics of Middle Jurassic age in the Statfjord oil-field of the North Sea. Neues Jahrbuch fur Mineralogie, Geologie und Paläontologie. Monatshefte 10, 607-618.

Martin, C.A., Stewart, S.A., Doubleday, P.A., 2002. Upper carboniferous and lower Permian tectonostratigraphy on the southern margin of the central North Sea. J. Geol. Soc. Lond. 159, 731-749.

Mattey, D.P., Gibson, I.L., Marriner, G.F., Thompson, R.N., 1977. The diagnostic geochemistry, relative abundance, and spatial distribution of high-calcium, low-alkali olivine tholeiite dykes in the Lower Tertiary regional swarm of the Isle of Skye, NW Scotland. Mineral. Mag. 41, 273-285.

McDonough, W.F., Sun, S.S., 1995. The composition of the Earth. Chem. Geol. 120, 223-253.

Meschede, M., 1986. A method of discriminating between different types of mid-ocean ridge basalts and continental tholeiites with the Nb-Zr-Y diagram. Chem. Geol. 56, 207-218.

Monaghan, A.A., Pringle, M.S., 2004. 40Ar/39Ar geochronology of Carboniferous-Permian volcanism in the Midland Valley, Scotland. In: In: Wilson, M., Neumann, E.-R., Davies, G.R. (Eds.), Permo-carboniferous Magmatism and Rifting in Europe, vol. 223. Geological Society, London, Special Publication, pp. $219-242$.

Monaghan, A.A., Parrish, R.R., 2006. Geochronology of Carboniferous-Permian magmatism in the Midland Valley of Scotland: implications for regional tectonomagmatic evolution and the numerical time scale. J. Geol. Soc. Lond. 163, 15-28. http://dx.doi.org/10.1144/0016-764904-142.

Odinsen, T., Reemst, P., van der Beek, P., Faleide, J.I., Gabrielsen, R.H., 2000. Permo-Triassic and Jurassic extension in the northern North Sea: results from tectonostratigraphic forward modelling. In: In: Nøttvedt, A. (Ed.), Dynamics of the Norwegian Margin, vol. 167. Geological Society, London, Special Publication, pp. 83103. http://dx.doi.org/10.1144/GSL.SP.2000.167.01.05.

Ohm, S.E., Karlsen, D.A., Phan, N.T., Strand, T., Iversen, G., 2012. Present Jurassic petroleum charge facing Paleozoic biodegraded oil: geochemical challenges and potential upsides, Embla field, North Sea. AAPG Bull. 96, 1523-1552.

Olaussen, S., Larsen, B.T., Steel, R., 1994. The Upper Carboniferous-Permian Oslo Rift; basin fill in relation to tectonic development. In: In: Embry, A.F., Beauchamp, B., Glass, D.J. (Eds.), Pangea: Global Environments and Resources, vol. 17. Canadian Society of Petroleum Geologists Memoir, pp. 175-197.

Pearce, J.A., 1996. A user's guide to basalt discrimination diagrams. Trace element geochemistry of volcanic rocks: applications for massive sulphide exploration. Geological Association of Canada. Short. Course Notes 12, 113.

Pearce, J.A., Cann, J.R., 1973. Tectonic setting of basic volcanic rocks determined using trace element analyses. Earth Planet. Sci. Lett. 19, 290-300.

Pharaoh, T.C., 1999. Palaeozoic terranes and their lithospheric boundaries within the Trans-European Suture Zone (TESZ): a review. Tectonophysics 314, 17-41.

Pedersen, J.H., Karlsen, D.A., Spjeldnæs, N., Backer-Owe, K., Lie, J.E., Brunstad, H., 2007. Lower paleozoic petroleum from southern scandinavia: implications to a Paleozoic petroleum system offshore southern Norway. AAPG Bull. 91, 1189-1212. http://dx.doi.org/10.1306/03080706020.

Ramberg, I.B., Larsen, B.T., 1978. Tectonomagmatic evolution. In: In: Dons, J.A. (Ed.), The Oslo Paleorift: a Review and Guide to Excursions, vol. 337. Norges geologiske Undersøkelse, pp. 55-73.

Rattey, R.P., Hayward, A.B., 1993. Sequence stratigraphy of a failed rift system: the Middle Jurassic to Early Cretaceous basin evolution of the central and northern North Sea. In: Parker, J.R. (Ed.), Petroleum Geology of Northwest Europe: Proceedings of the 4th Conference. The Geological Society, London, pp. 215-249.

Robson, D., 1991. The Argyll, Duncan and Innes Fields, blocks 30/24, 30/25a, UK North Sea. In: Abbotts, I.L. (Ed.), United Kingdom Oil and Gas Fields. 25 Years Commemorative Volume, vol. 14. Geological Society, London, Memoirs, pp. 219-226.

Rock, N.M.S., 1983. The permo-carboniferous camptonite-monchiquite dyke-suite of the scottish highlands and islands: distribution, field and petrological aspects. Rep. Inst. Geol. Sci No. 82/14.

Rock, N.M., 1987. The nature and origin of lamprophyres: an overview. In: In: Fitton, J.G., Upton, B.G.J. (Eds.), Alkaline Igneous Rocks, vol. 30. Geological Society, London, Special Publication, pp. 191-226.

Scheck-Wenderoth, M., Lamarche, J., 2005. Crustal memory and basin evolution in the Central European Basin System; new insights from a 3D structural model, Integration of geophysical and geological data and numerical models in basins. Tectonophysics 397, 143-165. 
Şengör, A.M.C., Burke, K., 1978. Relative timing of rifting and volcanism on Earth and its tectonic implications. Geophys. Res. Lett. 5, 419-421.

Smith, K., Ritchie, J.D., 1993. Jurassic volcanic centres in the central North Sea. In: Parker, J.R. (Ed.), Petroleum Geology of Northwest Europe: Proceedings of the $4^{\text {th }}$ Conference. Geological Society, London, pp. 519-531.

Stemmerik, L., Ineson, J.R., Mitchell, J.G., 2000. Stratigraphy of the Rotliegend group in the Danish part of the northern Permian basin, North Sea. J. Geol. Soc. 157, 1127-1136.

Timmerman, M.J., 2004. Timing, geodynamic setting and character of Permo-Carboniferous magmatism in the foreland of the Variscan Orogen, NW Europe. Geol. Soc. Lond. Spec. Publ. 223, 41-74.

Timmerman, M.J., Heeremans, M., Kirstein, L.A., Larsen, B.T., Spencer-Dunworth, E.-.A., Sundvoll, B., 2009. Linking changes in tectonic style with magmatism in northern Europe during the late Carboniferous to latest Permian. Tectonophysics 437, 375-390.

Torsvik, T.H., Smethurst, M.A., Burke, K., Steinberger, B., 2008. Long term stability in deep mantle structure: evidence from the ca. 300 Ma Skagerrak-Centered Large Igneous Province (the SCLIP). Earth Planet. Sci. Lett. 267, 444-452.

Trewin, N.H., Fryberger, S.G., Kreutz, H., 2003. The Auk field, block 30/16, UK North Sea. In: In: Gluyas, J.G., Hichens, H.M. (Eds.), United Kingdom Oil and Gas Fields, Commemorative Millennium Volume, vol. 20. Geological Society, London, Memoirs, pp. 485-496.

Trewin, N.H., Bramwell, M.G., 1991. The Auk Field, Block 30/16, UK North Sea. Geological Society, London, Memoirs 14, pp. 227-236.

Underhill, J.R., Partington, M.A., 1993. Jurassic thermal doming and deflation in the North Sea: implication of the sequence stratigraphic evidence. In: In: Parker, J.R. (Ed.), Petroleum Geology of Northwest Europe: Bath Proceedings of the $4^{\text {th }}$ Conference, vol. 1. London, Geological Society, pp. 337-346.

Upton, B.G.J., Stephenson, D., Smedley, P.M., Wallis, S.M., Fitton, J.G., 2004. Carboniferous and permian magmatism in Scotland. In: In: Wilson, M., Neumann, E.-R., Davies, G.R., Timmerman, M.J., Heeremans, M., Larsen, B.T. (Eds.), Permo-Carboniferous Magmatism and Rifting in Europe, vol. 223. Journal of the Geological Society of London, Special Publication, pp. 195-218.

Wall, M., Cartwright, J., Davies, R., McGrandle, A., 2010. 3D seismic imaging of a tertiary dyke swarm in the southern North Sea, UK. Basin Res. 22, 181-194. http://dx.doi.org/10.1111/j.1365-2117.2009.00416.x.

Welin, E., 1979. Tabulation of recalculated radiometric ages published 1960-1979 for rocks and minerals in Sweden. Geol. Föreningens i Stockh. Förhandlingar 101, 309-320.

Winchester, J.A., Floyd, P.A., 1976. Geochemical magma type discrimination: application to altered and metamorphosed basin igneous rocks. Earth Planet. Sci. Lett. 28, 459-469.

Winchester, J.A., Floyd, P.A., 1977. Geochemical discrimination of different magma series and their differentiation products using immobile elements. Chem. Geol. 20, 325-343.

Wood, D.A., 1980. The application of a Th-Hf-Ta diagram to problems of tectonomagmatic classification and to establish the nature of crustal contamination of basaltic lavas of the British Tertiary Volcanic Province. Earth Planet. Sci. Lett. 50, 11-30.

Ziegler, P.A., 1990. Geological Atlas of Western and Central Europe, second ed. Shell Internationale Petroleum Maatschappij B.V., The Hague, Netherlands 1e239.

Ziegler, P.A., 1992. North Sea rift system. In: In: Ziegler, P.A. (Ed.), Geodynamics of Rifting, Volume I. Case History Studies on Rifts: Europe and Asia. Tectonophysics, vol. 208. pp. 55-75.

Ziegler, P.A., Dèzes, P., 2006. Crustal evolution of western and central Europe. Geol. Soc. Lond. Memoirs 32, 43-56. http://dx.doi.org/10.1144/GSL.MEM.2006.032.01.03. 


\section{Captions}

Fig. 1. Sketch map with structural elements of the Palaeozoic post-Caledonian North Sea region. The Embla and Flora oil fields are located on the flank of the Mid North Sea High, ca. $30 \mathrm{~km}$ apart. Late Devonian proto-Central Graben after Lundmark et al. (2012). Major late Carboniferous - early Permian in- and extrusive magmatic provinces are shown (after Torsvik et al., 2008; Timmerman et al., 2009), with Scottish alkaline (lamprophyric) dike swarms represented by azimuth rose diagrams (Upton et al., 2004; after Rock, 1983) and the location of the proposed late Carboniferous - early Permian hot spot centre (Torsvik et al., 2008). MV = Midland Valley; MNSH-RFH = Mid North Sea High - Ringkøbing Fyn High; SU = Southern Uplands.

Fig. 2. Schematic lithological logs (not to scale) with sample numbers and measured depth in metres. Samples 40 and 41 represent Embla shale.

Fig. 3. a-e. Thin section images in plain polarized light of representative samples in this study. a) Sample 64. b) Sample 62. c) Sample 22. d) Sample 70. e) Sample 69.

Fig. 4. Selected element geochemistry normalized to primordial mantle after McDonough and Sun (1995). To account for high volatile contents the figure shows data recalculated to $100 \%$ dry. The geochemical patterns are consistent with three groups of rocks, A, B and C. Shaded area outlines geochemistry of late Devonian Embla shales (samples 40, 41). Legend shows well, sample no., measured depth in metres, and symbol used in diagram.

Fig. 5. a-h. Bivariate plots with calculated trend lines for groups A, B and C. The figure is based on data recalculated to $100 \%$ dry. In group A sample 62 is excluded from the calculated trend lines (see text for explanation). Legend as in Fig. 4 a) Harker diagram of Al2O3 content. b-h) Selected element oxides (\%) vs. LOI (\%). In diagram d) sample 64 is not included in calculated trend line.

Fig. 6. a,b. High field strength element based classification diagrams. Legend as in Fig. 4 a) $\mathrm{Zr} / \mathrm{TiO} 2 \mathrm{vs}$. Nb/Y diagram after Pearce (1996; modified from Winchester and Floyd, 1977). The Zr/TiO2 data indicate a low degree of magmatic differentiation, and the $\mathrm{Nb} / \mathrm{Y}$ data indicate variable degrees of alkalinity. b) $\mathrm{Nb} / \mathrm{Y} \mathrm{vs}$. $\left(\mathrm{Zr} / \mathrm{P} 2 \mathrm{O} 5^{*} 1000\right)$ diagram and diagnostic criteria after Floyd and Winchester (1975), boundary line after Winchester and Floyd (1976). Group A is transitional according to the diagnostic criteria, group B is alkaline, and group $\mathrm{C}$ is tholeiite basaltic.

Fig. 7. a, b. Ternary HFS element based discrimination diagrams for basalts. Legend as in Fig. 4 a) Th-(Hf/3)-Ta after Wood (1980). Sample 62, a mix of volcanic and siliciclastic sediments, plot in the lower left corner of the diagram and is used as a proxy for crustal contamination. b) ( $\mathrm{Zr} / 4)-(\mathrm{Nb} * 2)-\mathrm{Y}$ after Meshede (1986).

Fig. 8. a,b. Ce/Y v. Zr/Nb diagrams (after Upton et al., 2004, and references therein). The ratios can be used to approximate degree of melting and source composition, and to characterize the different magmatic groups according to their HFS element signatures. Legend as in Fig. 4 a) Analyses of igneous rocks from the Embla oil field compared to sub-alkaline and alkaline Permo-Carboniferous mafic igneous rocks and Ocean Island Basalt (OIB) after Upton et al., (2004) (shaded area), and Flora oil field basalt from Heeremans et al., (2004). b) Same as above but compared to Jurassic mafic igneous rocks (after Bergelin et al. 2011). Note the distinctive character of the late Jurassic Embla basalts.

Fig. 9. Mid and late Jurassic uplift, faulting and magmatism in the North Sea region (after Coward et al., 2003). Rattray and Ron Volcanic Provinces are shown on map. CG = Central Graben; EB=Egersund Basin; MFG=Moray Firth Graben; VG=Viking Graben.

Table 1. Samples in this study. Measured depth (MD) in metres.

Table 2. Whole-rock geochemical analyses of samples from the Embla field in this study. Fe2O3(T)= total Fe expressed as Fe2O3. Samples 40 and 41 represent late Devonian Embla shale included for comparison. 
Figures and Tables

Figure 1.

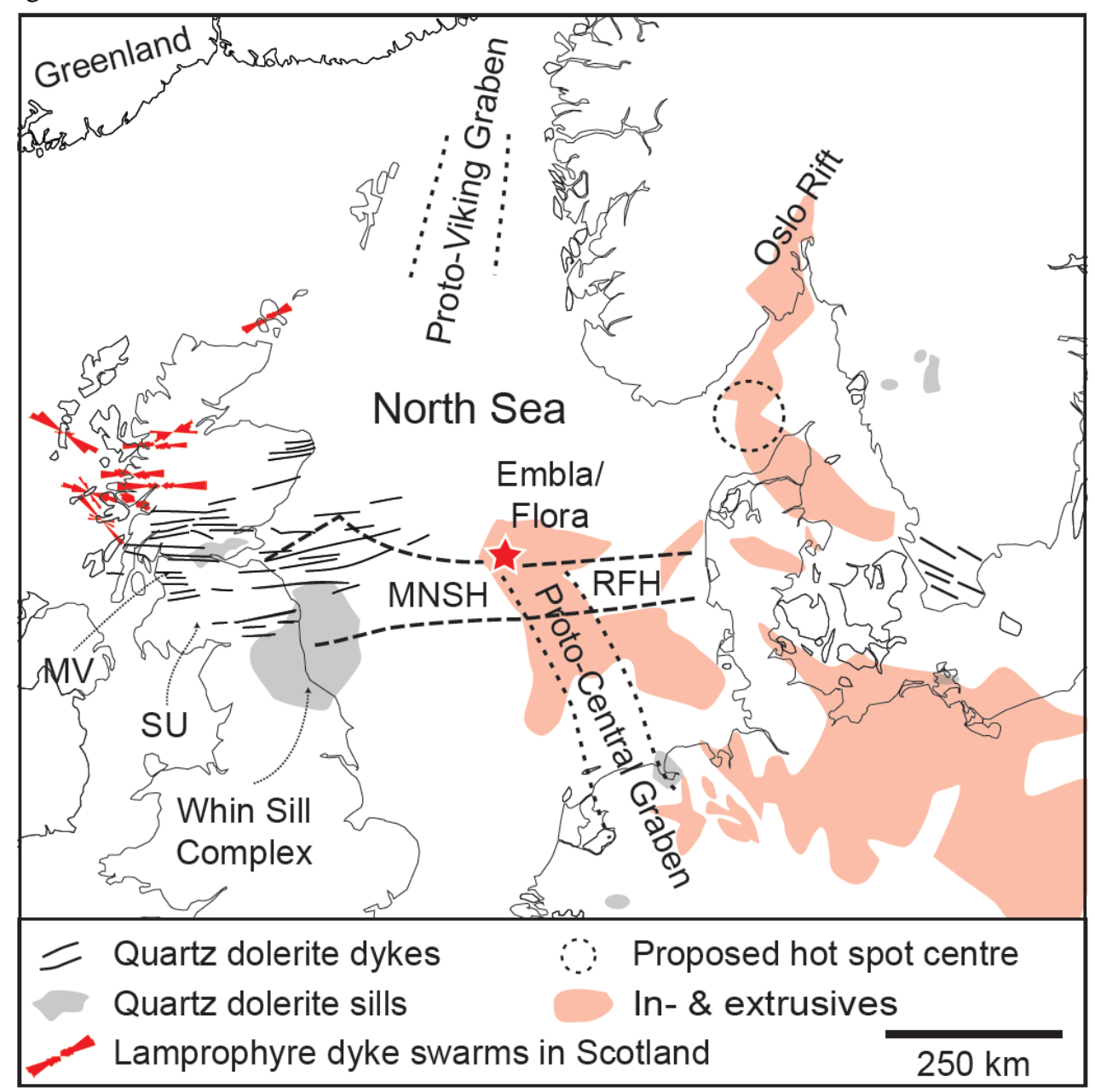


Figure 2.

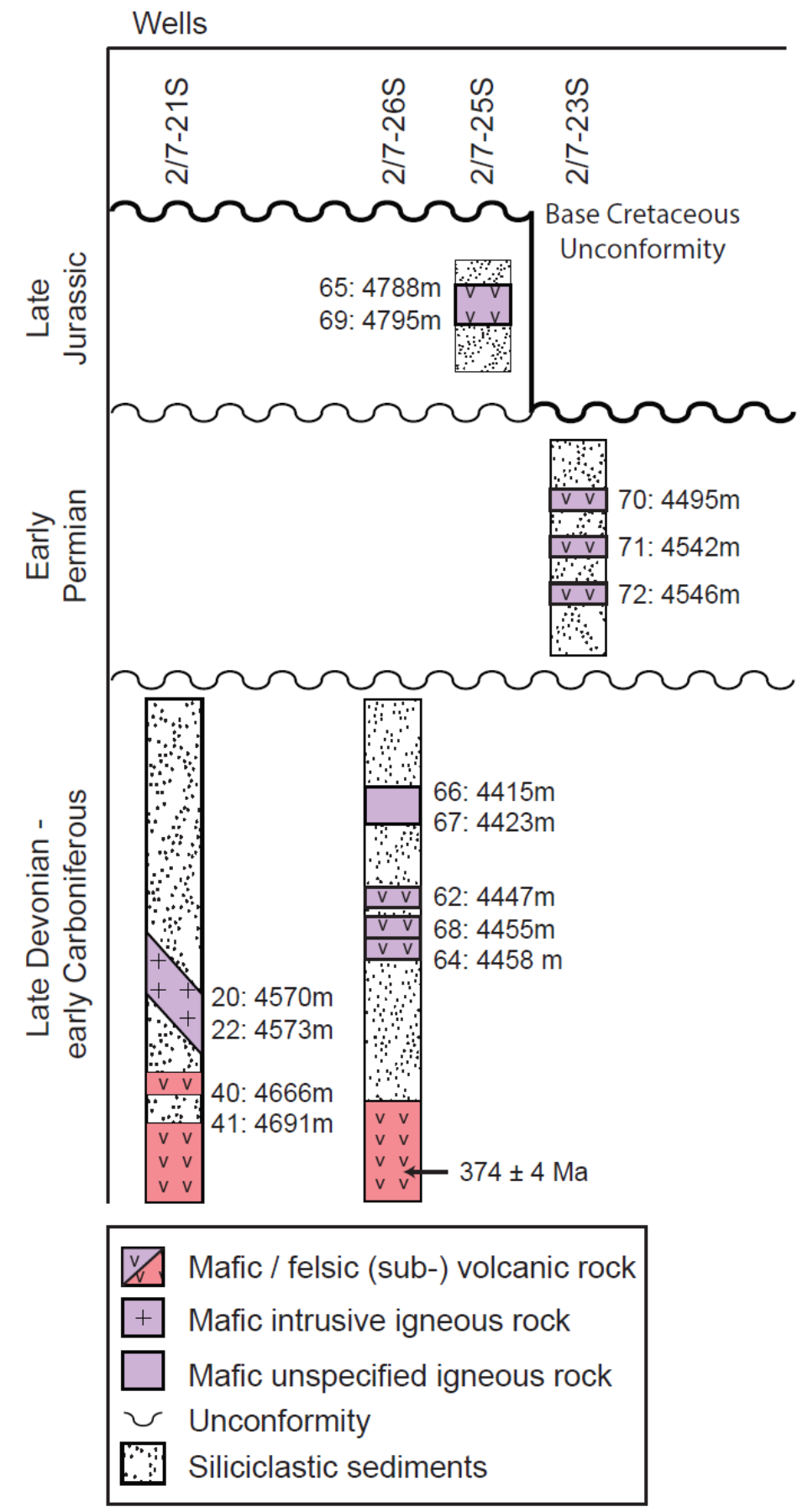



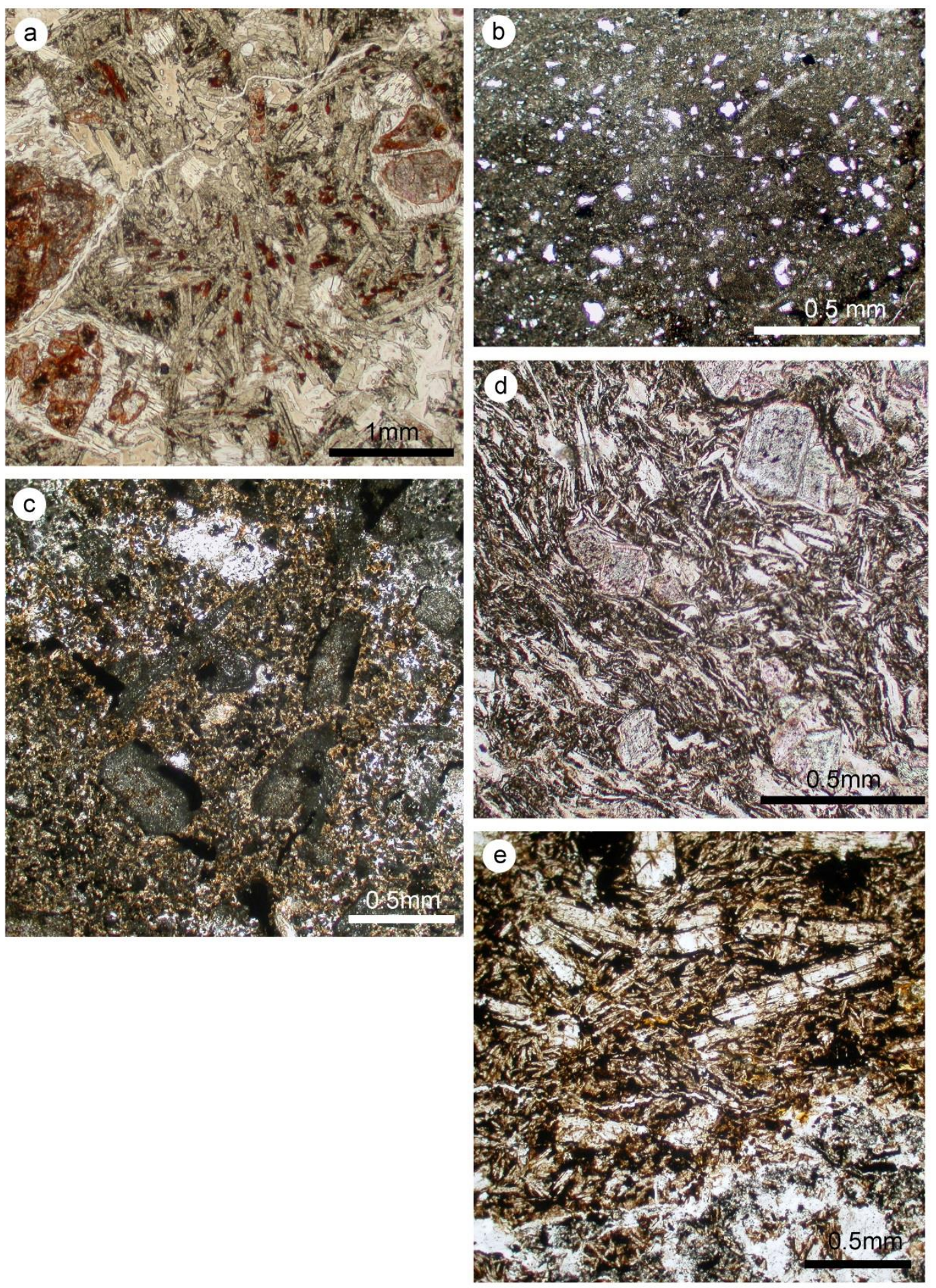
Figure 4.

\begin{tabular}{|c|c|c|}
\hline LEGEI & & \\
\hline Group & $A_{1}$ & e Devor \\
\hline $2 / 7-26 S$ & 66 & $4415 \mathrm{~m}$ \\
\hline & 67 & $4423 \mathrm{~m}$ \\
\hline & 62 & $4447 m \Delta$ \\
\hline & 68 & $4455 \mathrm{~m}$ \\
\hline & 64 & $4458 \mathrm{~m}$ \\
\hline Group & $B(e$ & rly Pern \\
\hline $2 / 7-23 S$ & 70 & $4495 \mathrm{~m}$ \\
\hline & 71 & $4542 \mathrm{~m}$ \\
\hline & 72 & $4546 \mathrm{~m}$ \\
\hline $2 / 7-21 \mathrm{~S}$ & 20 & $4570 \mathrm{~m}$ \\
\hline & 22 & $4573 m$ \\
\hline roup & C (I & te Jurass \\
\hline $2 / 7-25 S$ & 65 & $4788 m$ \\
\hline
\end{tabular}

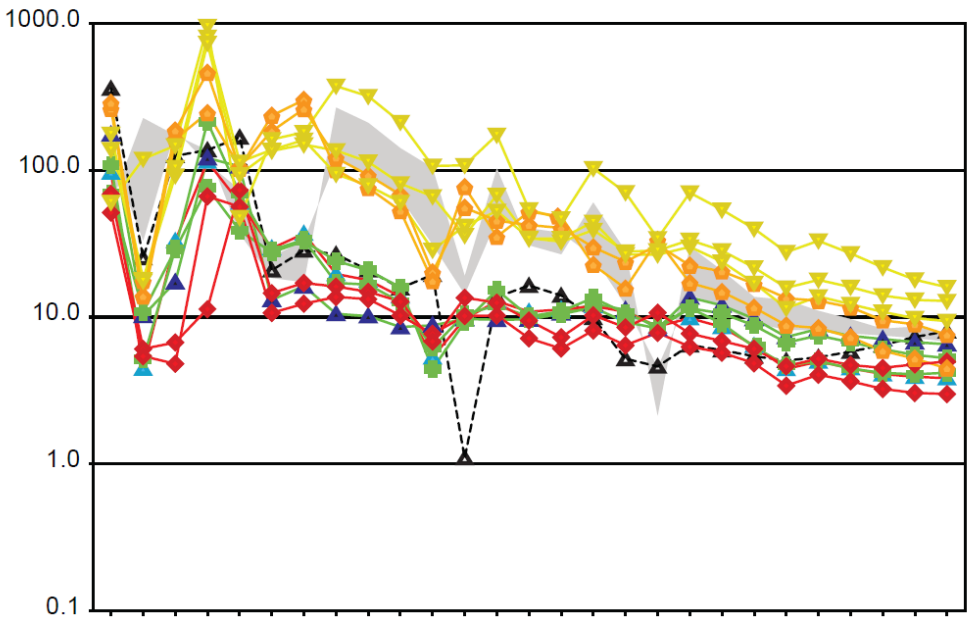

Rb BaTh U K NbTa La Ce Pr Sr P Nd Zr Hf SmEu Ti Gd Tb Dy Y HoEr TmYb Lu

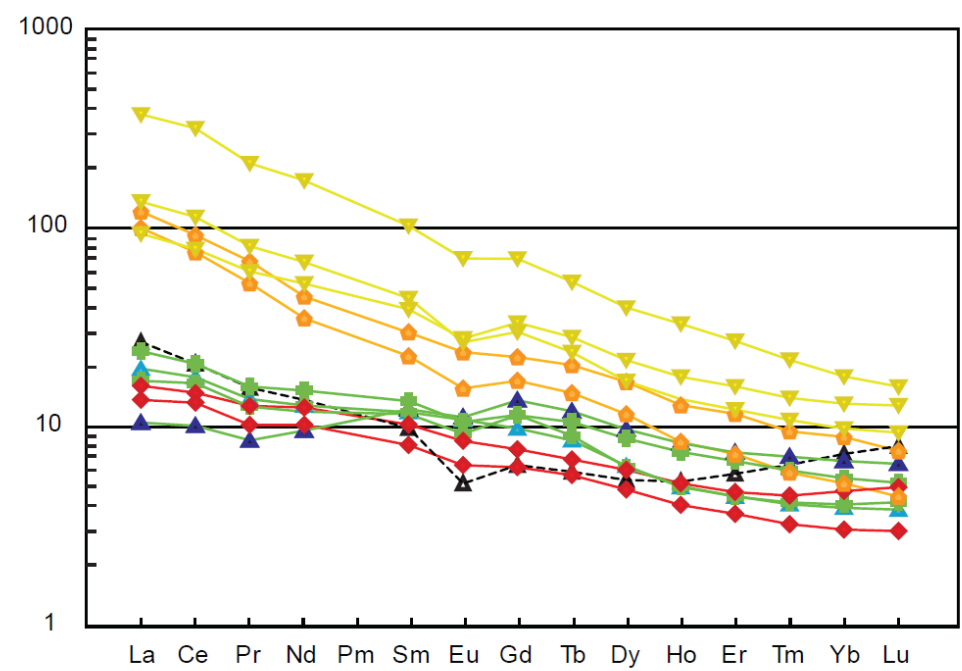


Figure 5.
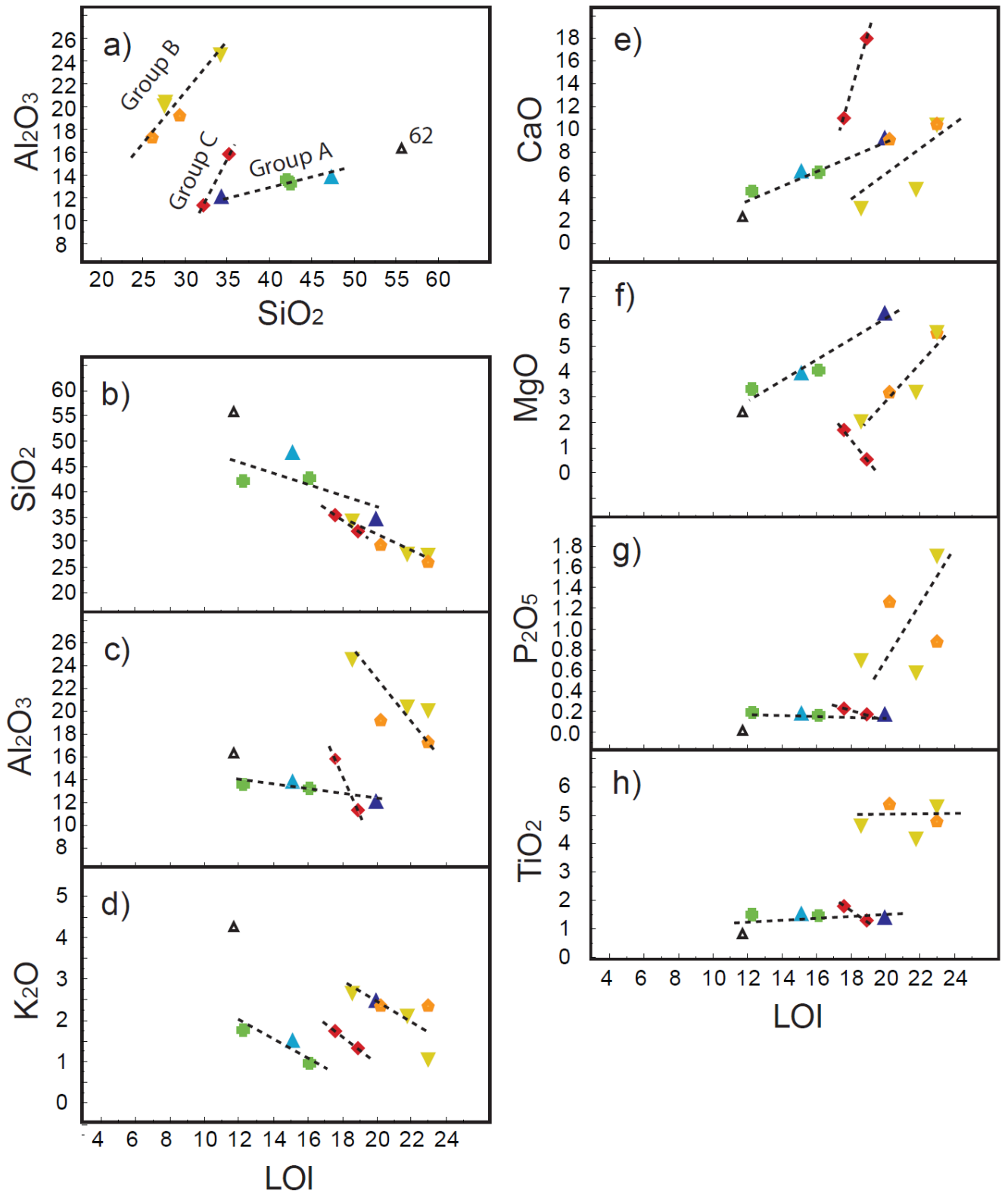
Figure 6.
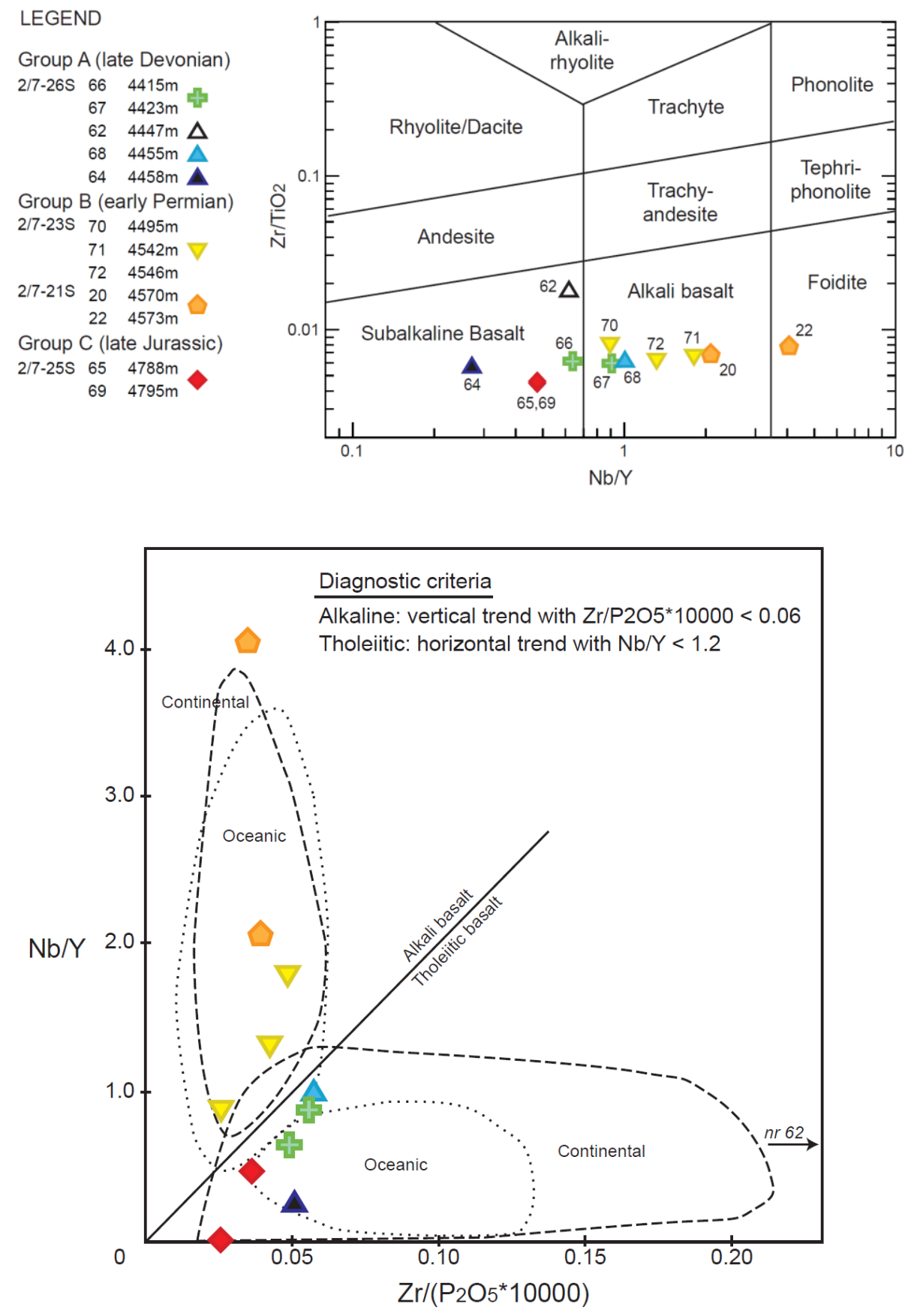
Group A (late Devonian) 도 $\triangle$

Group B (early Permian) $\nabla \mathrm{C}$

Group C (late Jurassic)

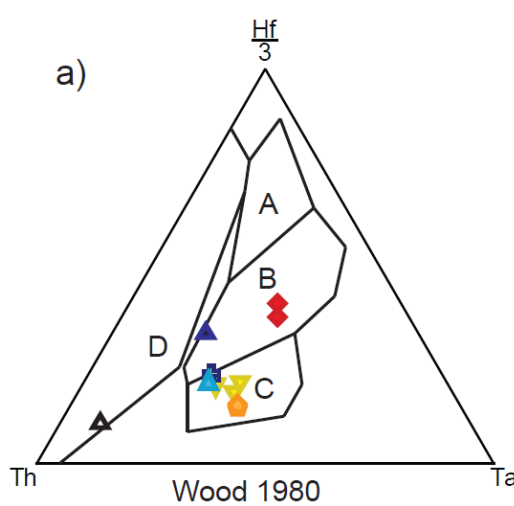

A: N-Type MORB

$B$ : E-Type MORB

Within PI. Tholeiites

C: Alk. Within Pl. Basalts

D: Volc. Arc Basalts

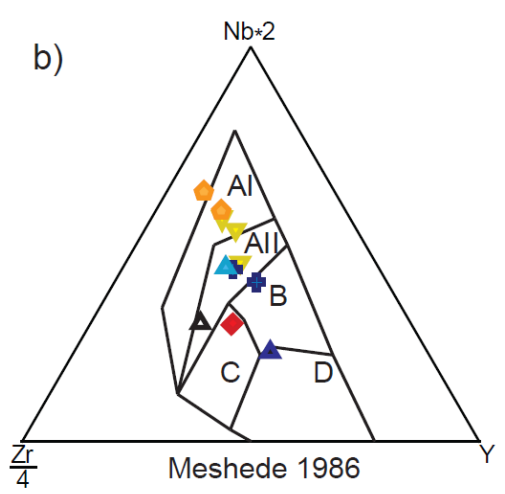

Al: Within PI. Alk. Basalts

All: Within PI. Alk. Basalts

Within PI. Tholeiites

B: E-Type MORB Within PI. Tholeiites

C: Volc. Arc Basalts
D: N-Type MORB 
Figure 8.

a)

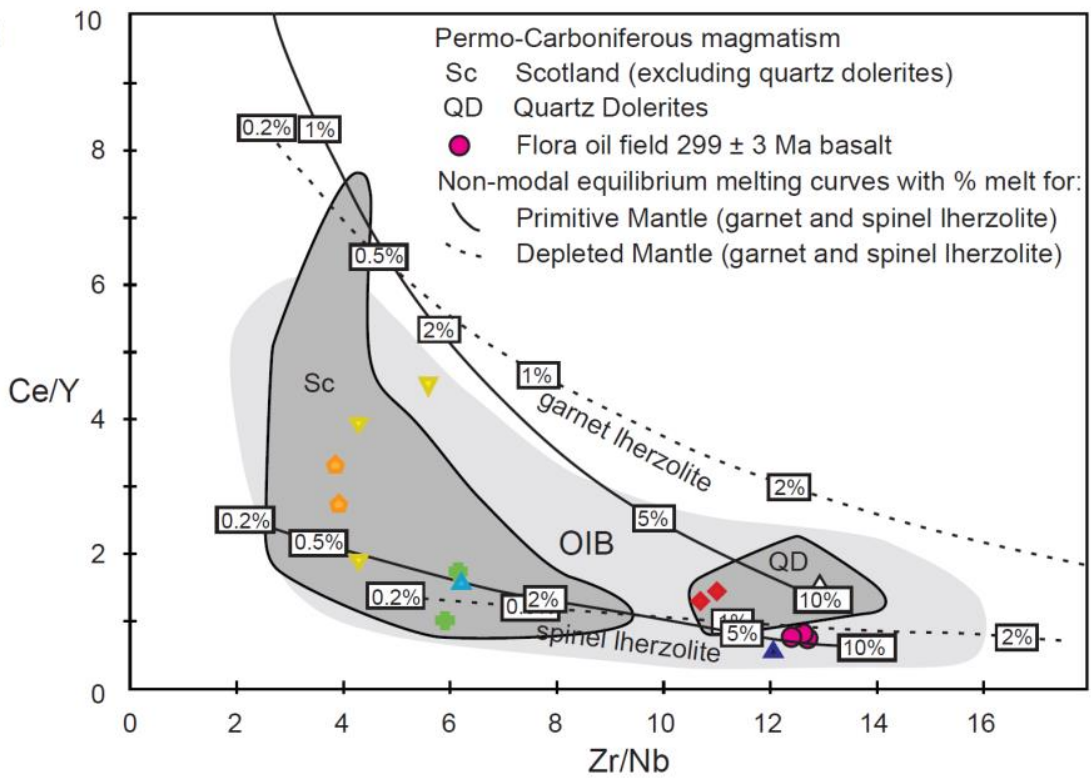

b)

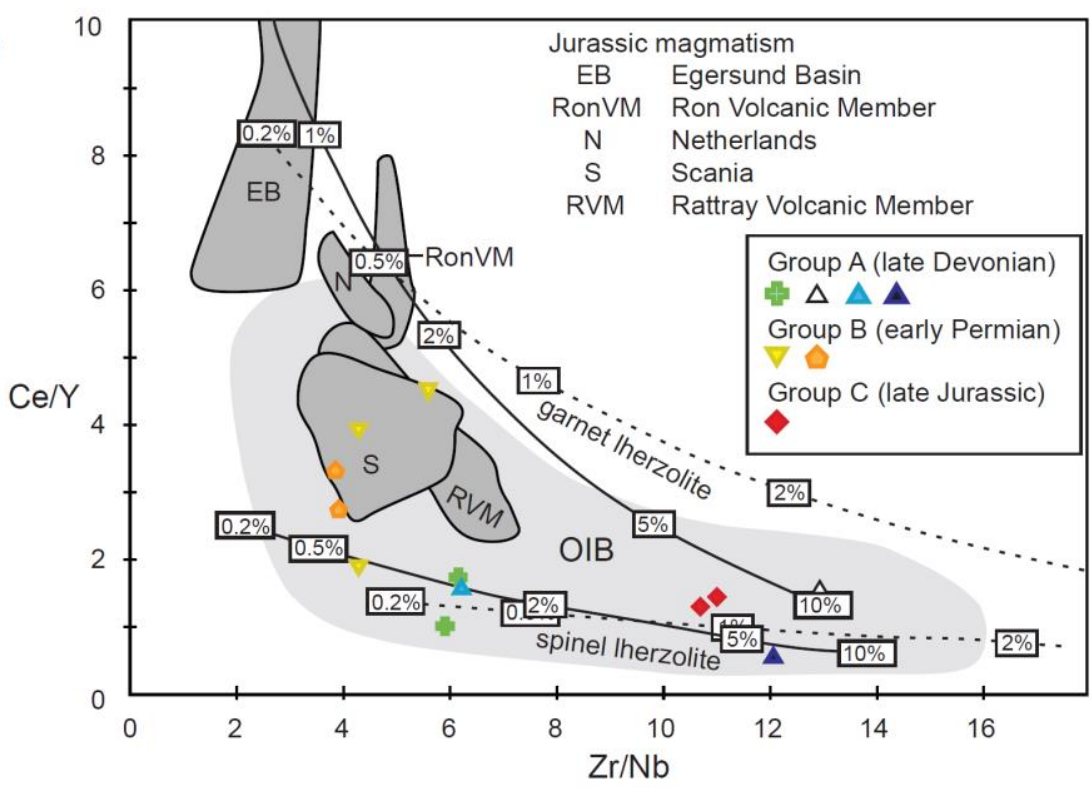


Figure 9.

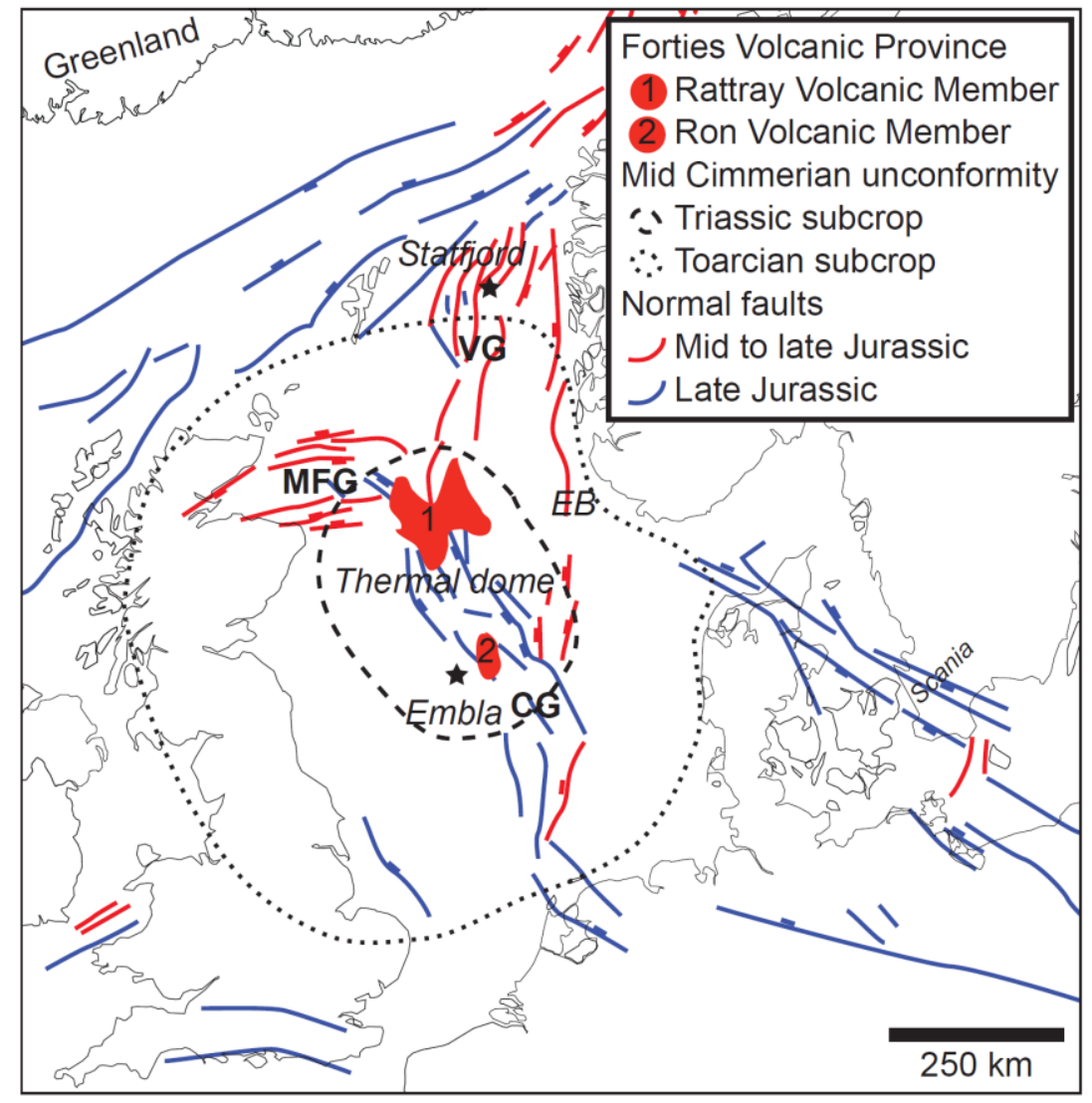


Table 1.

\begin{tabular}{|c|c|c|c|c|c|c|c|}
\hline Well & $\begin{array}{l}\text { Depth } \\
\text { (meter) }\end{array}$ & $\mathrm{Nr}$ & Contacts & $\begin{array}{l}\text { Rock } \\
\text { textures }\end{array}$ & $\begin{array}{l}\text { Phenocryst } \\
\text { pseudomorphs }\end{array}$ & Main alteration & $\begin{array}{l}\text { Type of } \\
\text { deposit }\end{array}$ \\
\hline \multirow{2}{*}{$\begin{array}{l}2 / 7- \\
25 S\end{array}$} & 4788 & 65 & \multirow{2}{*}{ Not exposed } & \multirow{2}{*}{$\begin{array}{l}\text { Porphyric, } \\
\text { flow banding }\end{array}$} & \multirow{2}{*}{$\begin{array}{l}\text { Plagioclase, } \\
\text { pyroxene }\end{array}$} & \multirow{2}{*}{ Albite, calcite } & \multirow{2}{*}{ Lavaflow } \\
\hline & 4795 & 69 & & & & & \\
\hline \multirow{3}{*}{$\begin{array}{l}2 / 7- \\
23 S\end{array}$} & 4495 & 70 & \multirow{3}{*}{ Depositional } & \multirow{3}{*}{$\begin{array}{l}\text { Mainly } \\
\text { aphanitic, } \\
\text { flow banding }\end{array}$} & \multirow{3}{*}{ Plagioclase } & \multirow{3}{*}{ Kaolin, illite, dolomite, hematite } & \multirow{3}{*}{ Lavaflow } \\
\hline & 4542 & 71 & & & & & \\
\hline & 4546 & 72 & & & & & \\
\hline \multirow{4}{*}{$\begin{array}{l}2 / 7- \\
21 S\end{array}$} & 4570 & 20 & \multirow{2}{*}{$\begin{array}{l}\text { Crosscutting } \\
\text { sediments }\end{array}$} & \multirow{2}{*}{ Porphyric } & \multirow{2}{*}{$\begin{array}{l}\text { Plagioclase, } \\
\text { pyroxene, } \\
\text { olivine(?) }\end{array}$} & \multirow{2}{*}{ Kaolin, illite, dolomite } & \multirow{2}{*}{ Dyke } \\
\hline & 4573 & 22 & & & & & \\
\hline & 4666 & 41 & & & & & Shale \\
\hline & 4691 & 40 & & & & & \\
\hline \multirow{5}{*}{$\begin{array}{l}2 / 7- \\
26 S\end{array}$} & 4415 & 66 & \multirow[b]{2}{*}{ Not exposed } & \multirow[b]{2}{*}{ Porphyric } & \multirow{2}{*}{$\begin{array}{l}\text { Plagioclase, } \\
\text { pyroxene, } \\
\text { olivine(?) }\end{array}$} & \multirow[b]{2}{*}{ Kaolin, illite, dolomite, hematite } & \multirow{2}{*}{$\begin{array}{l}\text { Lava or sub - } \\
\text { volcanic } \\
\text { intrusion }\end{array}$} \\
\hline & 4423 & 67 & & & & & \\
\hline & 4447 & 62 & Not exposed & $\begin{array}{l}\text { Aphanitic / } \\
\text { sedimentary }\end{array}$ & Not observed & Kaolin, illite, dolomite, hematite & $\begin{array}{l}\text { Volcaniclastic } \\
\text { sediments }\end{array}$ \\
\hline & 4455 & 68 & Depositional & Porphyric & $\begin{array}{l}\text { Plagioclase, } \\
\text { pyroxene, } \\
\text { olivine(?) }\end{array}$ & Kaolin, illite, dolomite, hematite & \multirow[t]{2}{*}{ Lavaflow } \\
\hline & 4458 & 64 & Depositional? & Porphyric & Plagioclase & Kaolin, illite, dolomite, hematite & \\
\hline
\end{tabular}


Table 2.

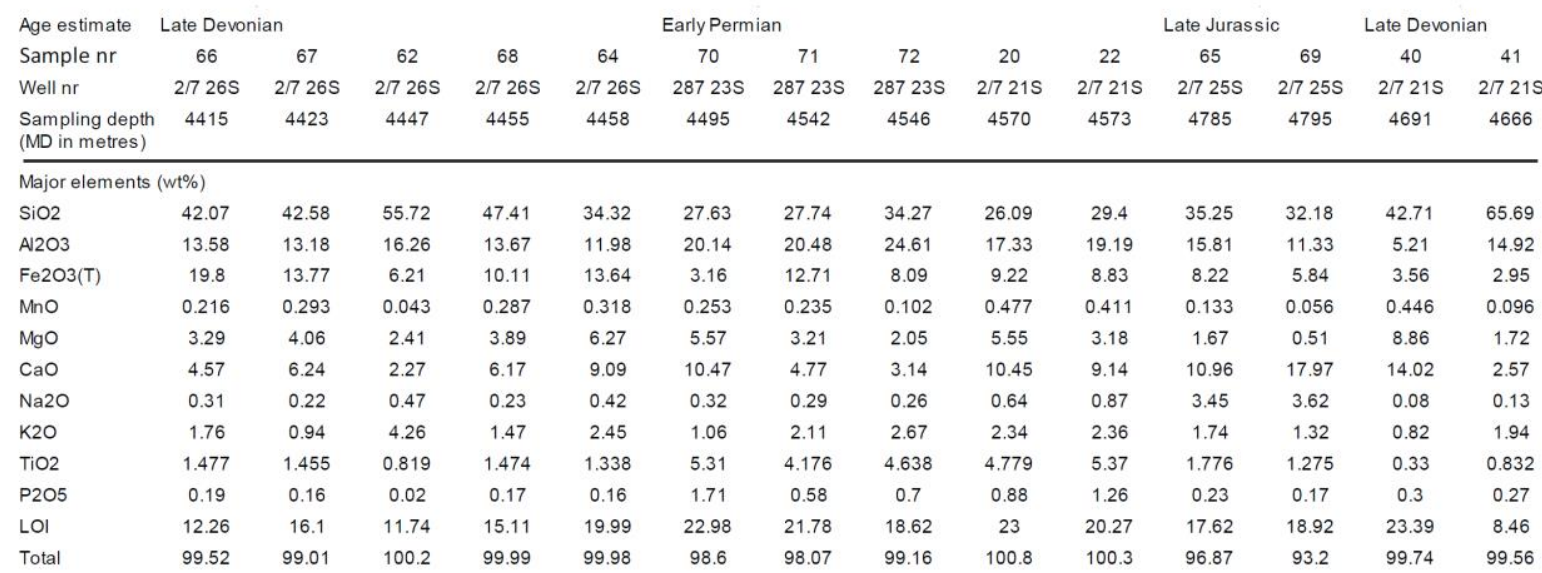

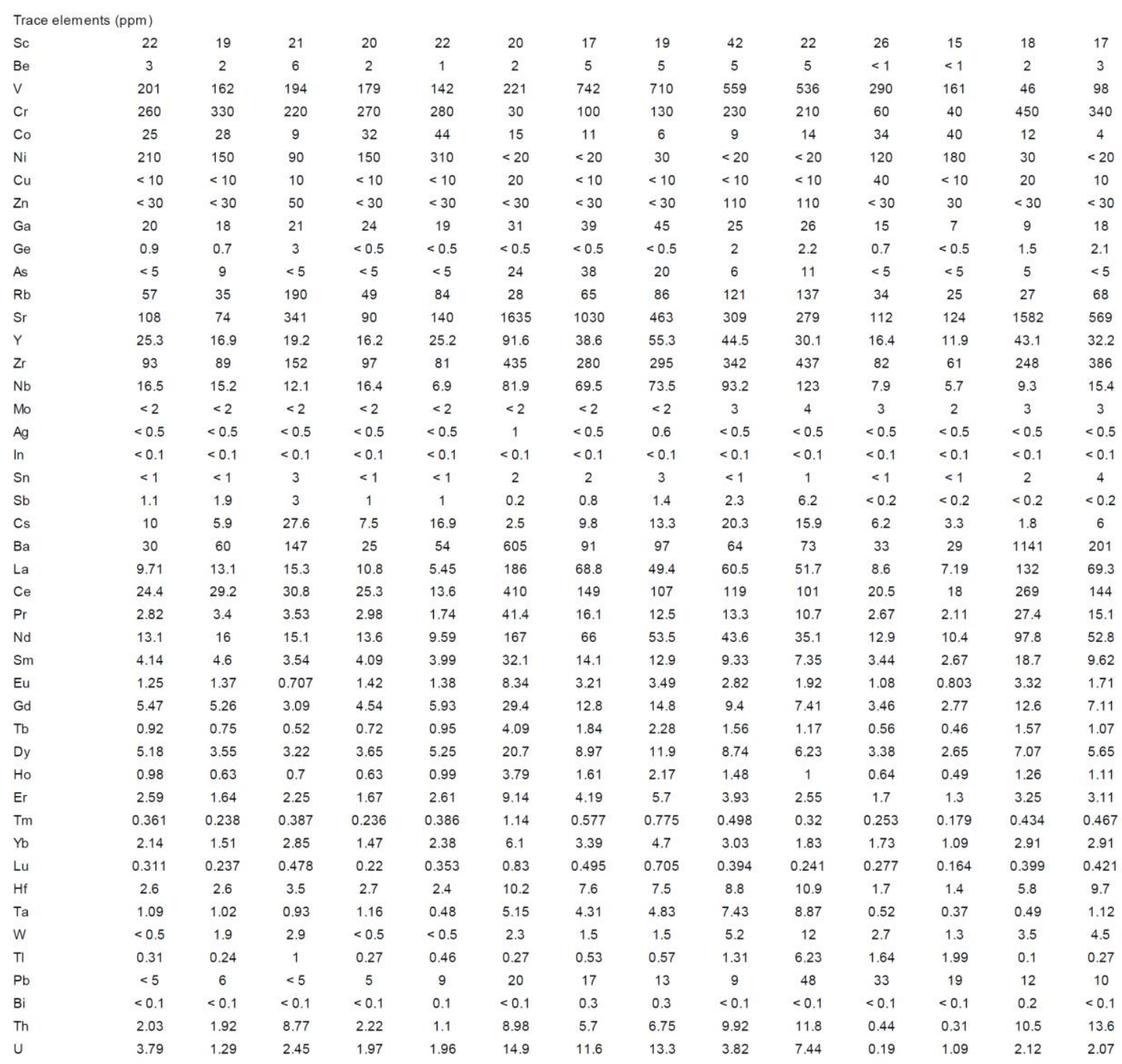

